\title{
NICKEL-HYDROGEN REACTORS: HEAT GENERATION, ISOTOPIC AND ELEMENTAL COMPOSITION OF FUEL
}

\author{
Alexander G. Parkhomov, Sergey N. Zabavin, Timur R. Timerbulatov \\ Experimental-design laboratory "K.I.T." \\ Moscow 121108, Russian Federation \\ alexparh@mail.ru, sergeyzabavin@gmail.com, konfi1@konfi.ru
}

Kirill A. Alabin, Stepan N. Andreev

Prokhorov General Physics Institute of the Russian Academy of Sciences, http://www.gpi.ru

Moscow 119991, Russian Federation

alabin.kirill@gmail.com, naukagpi@yandex.ru,

\section{Alexander G. Sobolev}

Lebedev Physical Institute of the Russian Academy of Sciences, http://www.lebedev.ru

Moscow 119991, Russian Federation

asob09@gmail.com

Abstract. At the interaction of hydrogen with a number of metals, including Nickel, are observed not only mechanical and chemical changes, but also such extraordinary phenomena as the anomalously large heat generation and the change in isotopic and elemental composition. An overview of experiments that explore these phenomena is presented. Also the results of analysis of the isotopic and elemental composition of the fuel and substances near the active zone of nickel-hydrogen reactors before and after work with the production of excess energy to $790 \mathrm{MJ}$ are presented. Reliable changes in the isotopic composition of nickel and lithium are not detected. A significant increase in the concentration of impurities of a number of nuclides discovered, not only in fuel but also in structural elements adjacent to the active zones of reactors.

Keywords: hydrogen, nickel, heat generation, isotopic composition, radiation

UDC 53.043

Bibliography - 30 references

Received 19.06.2017

RENSIT, 2017, 9(1):74-93

DOI: $10.17725 /$ rensit.2017.09.074

\section{Contents}

1. INTRODUCTION (74)

2. First experiments With Nickel Saturated WITH HYDROGEN (75)

3. Andrea Rossi's heatgenerator (77)

4. Attempts to reproduce Rossi reactors (80)

5. Estimation of possible changes of the ISOTOPE COMPOSITION OF FUEL (82)

6. REACTOR AP2 (82)

7. Reactor Protok-6 (83)

8. REACTOR VV3 (87)

9. REACtOR KB3 (88)

10. Discussion (90)

11. Conclusion (91)

ReferenCes (92)

\section{INTRODUCTION}

In March 1989 Fleishmann M., and S. Pons demonstrated the device, in which during the electrolysis of heavy water in the presence of a palladium cathode, emitted energy was several times more than supplied [1]. The authors explained this by the fact that released at the cathode deuterium penetrated into palladium, which has high ability to absorb hydrogen (deuterium). High concentration of deuterium nuclei, introduced into the crystal lattice of palladium, makes possible the fusion of two deuterium nuclei into the nucleus of helium or of tritium with the release of large energy.

Usually the history of studies of the anomalously large heat generation and other phenomena occurring at the feeding of some 
materials with hydrogen, one start with this demonstration, although the results indicating the existence of these phenomena were obtained before. For example, in 1950-ies I.S. Filimonenko has created an installation in which there was an unusually large heat generation at temperatures up to $1150^{\circ} \mathrm{C}$ [2]. The main part of Filimonenko reactor was a metal pipe made of an alloy containing palladium and filled of the deuterium.

Reaction of scientific community to the demonstration of Fleischmann and Pons was very boisterous. In scientific laboratories of different countries, attempts were made to repeat these experiments. But the poor reproducibility and the lack of clear explanation have led to the fact that a significant portion of the scientific community began to relate to the works in this area skeptical or even strongly negatively. Dislike was also contributed by the fact that this kind of phenomenon was called "cold fusion", though, from the point of view of the existing system of scientific knowledges, transformation of matter at the nuclear level at energies of the order of $1 \mathrm{eV}$ are impossible. But even if we assume the existence of some obscure mechanism of such nuclear transformations, they, according to existing ideas, inevitably must be accompanied by deadly gamma and neutron radiation. The fact that the researchers were not perish, it would seem, clearly demonstrated the fallacy of their experiments.

However, researches in this direction were continued [3-9]. The technique of such experiments is usually composed in saturating with hydrogen (deuterium) substances that have the ability to greedily absorb this gas (commonly used palladium, titanium or nickel). For this, in addition to just detention in the atmosphere of hydrogen are used electrolysis or electrical gas discharge. The hydrogen-saturated samples are subjected to different influences. In this case, are made a measurements, which may indicate the processes of the changes at the nuclear level. On the nuclear changes may indicate heat generation, exceeding the possibilities of chemical reactions, the appearance of neutrons, gamma and $\mathrm{x}$-ray radiation, the appearance of tritium, the change in isotopic composition. In addition, we studied the possibility of occurrence of nuclear transmutations in biological systems was studied $[10,11]$.

In this article presents information on the results of the analysis of the heat generation and changes in the fuel and in construction materials that occurred in several nickel-hydrogen reactors created by our team.

\section{FIRST EXPERIMENTS WITH THE HYDROGEN-SATURATED NICKEL}

Until recently, among the researchers of the phenomenon of anomalous heat generation received the most attention the palladium or titanium, with the most striking ability to absorb hydrogen. Although already in 1992 at the physics faculty of the University of Siena (Italy) by a group of researchers led by Francesco Piantelli experiments were conducted in which it was found anomalously large heat in the interaction with hydrogen with nickel [12].

In Fig. 1 the layout of the experimental setup is shown. Reactor chamber of length 100 $\mathrm{mm}$ has a diameter of $50 \mathrm{~mm}$. In the chamber is a heater of platinum wire. Inside the heater is placed, or a rod of Nickel with a length of 90 $\mathrm{mm}$ with a diameter of $5 \mathrm{~mm}$, or alternatively, an appropriate dummy stainless-steel rod of

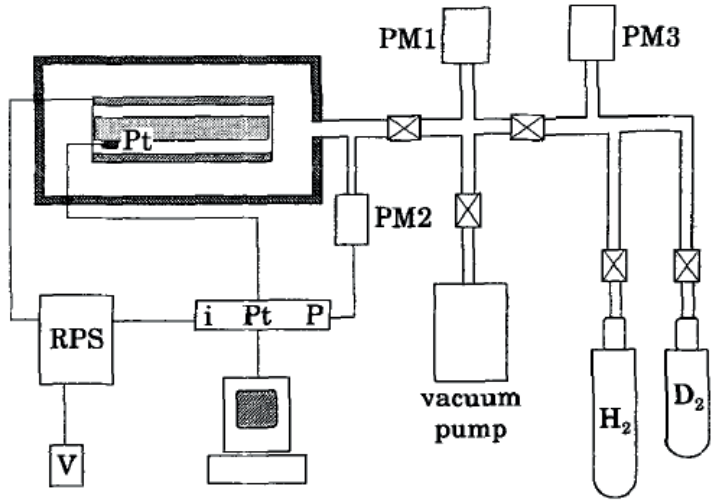

Fig. 1. Scheme of setup for the saturation of nickel with bydrogen and of study of heat generation [12]. 
the same size. The temperature of these rods was measured by a platinum thermometer. The chamber can be evacuated by means of a turbomolecular vacuum pump and filled with hydrogen or deuterium from gas bottles. The pressure inside the chamber is measured by a piezomanometer. The heater coil is powered DC stabilized power supply. The values of the gas pressure, the heater current and the temperature are continously monitored by a PC operated data logger.

Calibration measurements of the temperature dependence of the stainless steel rod upon heating power at pressures in the range from the maximum attainable vacuum up to atmospheric was made. Further, in setup placed a rod of nickel and cyclically carried out the pumping out and filling of the chamber with hydrogen (natural mixture of protium and deuterium) up to a pressure of about 0.55 bar at a temperature of $440^{\circ} \mathrm{C}$. Every time the pressure stabilized an hour after reducing the pressure about on 0.05 bar as a result of absorption of hydrogen by the nickel.

In one of the cycles of pumping-filling, the temperature suddenly rose from $440^{\circ}$ to $480^{\circ} \mathrm{C}$ at a constant power of electric heating. Using the calibration curve heating power-temperature, the authors concluded that unto the electrical heating has become add heat, to the power of

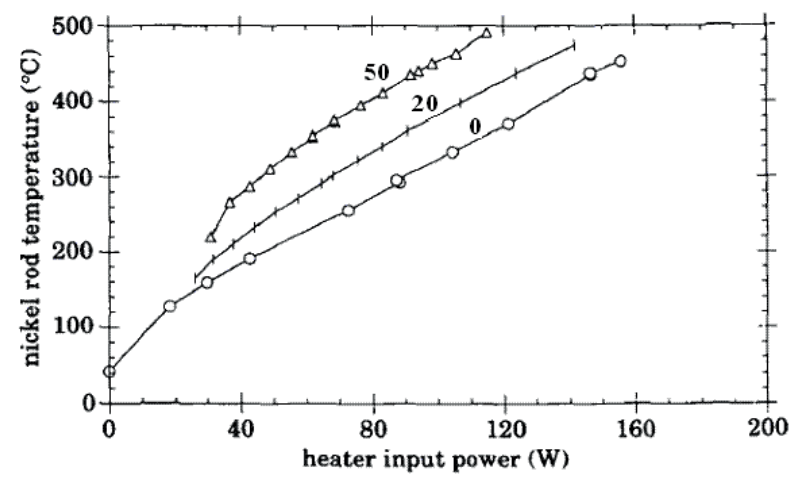

Fig. 2. The temperature of the rod in depending on the power of the electrical heating at different values of the anomalous energy release $0 \mathrm{~W}, 20 \mathrm{~W}, 50 \mathrm{~W}[12]$. The dependence in " 0 " is obtained for the stainless steel rod and rod of nickel is not saturated with bydrogen. about 20W. After several additional cycles the excess power reached 50 watts (Fig. 2).

Fig. 2 shows that the same temperature of nickel rod, which saturated with hydrogen, is achieved at a power of about two times smaller than when using the dummy or nickel, which not saturated with hydrogen.

The setup work lasted continuously for 24 days, with an average excess power of 44 watts. In total for this time produced about $90 \mathrm{MJ}$ of thermal energy in excess of electricity consumed.

In the future, were created a similar, but more advanced setups [13-15]. One of them, producing 68 watts of excess capacity, worked for 278 days, producing $900 \mathrm{MJ}$ of heat, above of electricity consumed. Other, producing 18 watts of excess capacity, worked 319 days, producing about $600 \mathrm{MJ}$ of heat in excess of electricity consumed. So much heat is released during the combustion of more $10 \mathrm{~kg}$ of oil products. Note that the mass of hydrogen absorbed by nickel, and partially reacted, is less than $100 \mathrm{mg}$.

After operation of the reactor for 22 days (produced $35 \mathrm{MJ}$ surplus energy) surface of the nickel sample was subjected to analysis using scanning electron microscope [13]. It revealed the presence of chromium and manganese, the presence of these was not noticeable prior to being in the reactor.

For clarification of the radiation situation around reactors were carried out special researches with the involvement of experts in the field of registration of nuclear radiation. To measurement of a possible neutron radiation were used three $3 \mathrm{He}$ counter surrounded by a paraffin retarders, and also an activation method using gold foil [14]. With the excessive power of heat generation 22-38 W was registered the unstable emission to 6.000 neutrons per second. It this to 1011 times less than would be emitted if the excess power was called the known mechanisms of nuclear reactions.

The possible gamma radiation was detected by the scintillation $\mathrm{NaI}(\mathrm{Tl})$ and also the semiconductor germanium detector. 
The measurement results differed little from natural background radioactivity [15]. In later experiments, it was discovered weak radiation with an energy of $511 \mathrm{Kev}$, which indicates the occurrence of $\beta^{+}$-decays. Description of the experiments of the Italian physicists, continue to the present time, can be found on the website [16]. One of the setups worked for several months without additional power supply and without added hydrogen, is continuously allocating 70 watts of thermal power.

The radiation of neutrons was registered as well by the Russian researchers during heating in the temperature range $250-350^{\circ} \mathrm{C}$ the nickel powder in a hydrogen environment at a pressure to 100 bar [17]. The radiation of neutrons took place in the form of short bursts or series of bursts lasting up to several tens of minutes. The total neutron yield reached 500000. For registration of neutrons was used $3 \mathrm{He}$ counter with a water retarder as well as an activation technique using indium. The results of the measurements by both methods are within the possible errors are the same.

From other studies in which it was registered the heat generation in excess of electricity consumed, it should be noted the researches of team led by the fellow worker of Italian national Institute of nuclear physics Chelani Francesco [18], as well as Akito Takahashi (Osaka University) and Akira Kitamura (Kobe University) [19], studied the nanopowder alloy nickel-copper in the matrix of $\mathrm{ZrO}_{2}$. They registered the release of energy up to $800 \mathrm{eV}$ per one absorbed hydrogen atom, which is hundreds times greater than the energy release, which is possible in chemical reactions.

\section{ANDREA ROSSI'S HEATGENERATORS}

Despite these successes, until recently, the study of these anomalous phenomena professionals nuclear was not taken seriously. The situation changed when the Italian engineer Andrea Rossi and Professor of the University of Bologna Sergio Focardi managed to move from research mock-ups to setups that produce energy on an industrial scale [20].

For the first time a device which produces a heat to capacity of $12.5 \mathrm{~kW}$, were demonstrated January 15, 2011. "Fuel" of the reactor is the nickel and hydrogen. The structure of this device is described in patent [21], but the detailed description is a trade secret. During public demonstrations, observers were allowed only to inspect the unit outside, measure the input and output of energy and to monitor the level of radiation.

October 28, 2011, Rossi demonstrated the reactor, which for 5.5 hours had give power $470 \mathrm{~kW}$ in self-sustaining mode. Careful measurements of the radiation around the working installation have not revealed any noticeable differences from the background. Although achieved in the tests the results are impressive, the design of setup cannot be considered perfect, as it consisted of 300 modules, housed in a cargo container. For her work needed the balloons with hydrogen and a lot of water.

Reactors of other design Rossi demonstrated in December 2012, March 2013 and March 2014. These devices appeal to compactness and simplicity. The operation of these reactors was controlled by an international Commission of competent scientists who released two lengthy report [22, 23]. Of particular interest is the last report. Although it did not disclose the internal structure of the reactor shown, the detail observation of the device operation and the thoroughness of the tests allow you to guess a lot. The study was performed in Barbengo (Lugano, Switzerland) with the use of equipment which, according to experts, does not in any way connected with Andrea Rossi or his partners. In the work took part Giuseppe Levi (Bologna University, Italy), Evelyn Foschi (Bologna, Italy), Bo Höistad, Roland Pettersson and Lars Tegnér (Uppsala University, Sweden), and Hanno Essén (Royal Institute of Technology, Sweden), David Bianchini (expert in radiation measurements). 


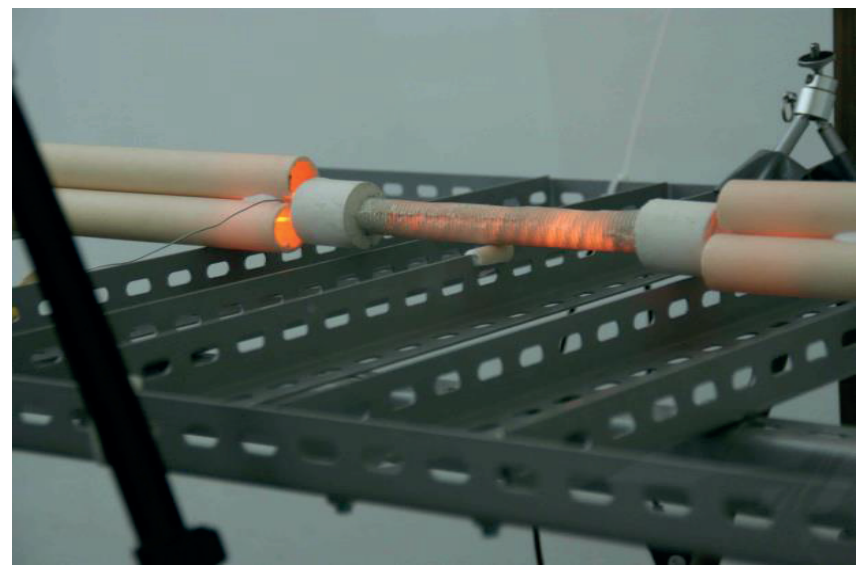

Fig. 3. The Rossi's reactor during the test. On each side there are three ceramic tubes with wires for which power is supplied, required for the preliminary beating of the reactor.

The presentment of this report was published in Russian [24].

The reactor weighs $450 \mathrm{~g}$. The appearance of the reactor is a ceramic cylinder of diameter 2 $\mathrm{cm}$ length $20 \mathrm{~cm}$ with overhangs that improve convective heat transfer (Fig. 3). On both sides this cylinder ends with two ceramic tips diameter $4 \mathrm{~cm}$, long $4 \mathrm{~cm}$. On the tips there are the clamps of three heaters. In one of the tips there is a hole with a diameter of $4 \mathrm{~mm}$. Into the hole is inserted ceramic plug in which is mounted the thermocouple probe. Through this hole is loaded the fuel.

Three phase power to the heaters is supplied from two sides via copper wires, located in ceramic tubes. To adjust the electric power programmable power supply was used, which uses to maintain the set mode the signal from the thermocouple probe.

For determining the consumed energy used power meters and spectrum analyzers, and digital multimer. The power generated was determined by measuring the surface temperature using thermal imaging cameras and calculation on this basis, the energy losses by radiation and convection. All used measuring equipment were tested at the manufacturing companies and crosschecked at the application site. The information coming from all sensors were recorded in the computer memory for later careful analysis.

All testing stages were under the continuous supervision of experts. In the first stage the reactor was investigated at idling speed (without fuel). In this case, the thermal energy dissipated by the reactor is equal to the amount of electricity supplied. This allowed to make calibration measurements, using the results of which it is possible to determine the energy release of the reactor in the operating mode.

After a 23-hour operation without fuel, the reactor was turned off and disconnected from electrical cables, which allowed to load fuel mass of about $1 \mathrm{~g}$, having the form of a fine powder. Before that, the powder to be loaded was poured into a special container, and its radioactivity was measured in a low-background lead chamber. After loading the fuel, the hole was closed with a ceramic stopper containing the thermocouple probe, and sealed with alumina cement. Were connected by electric cables and gradually increasing heating was included. The increase in heating power lasted as long as the average surface temperature of the reactor reached $1260^{\circ} \mathrm{C}$ at a power consumed by the heater of 810 watts. The operation in this mode lasted almost 10 days. At the end of this period the experts decided to increase the capacity, and raised it up to 900 watts. As a result, in a few minutes the temperature of the reactor was increased to $1400^{\circ} \mathrm{C}$. Such an increase in temperature corresponds to an increase in heat dissipation for $700 \mathrm{~W}$, although power of electric heating increased less than 100 watts. Further work took place when the electrical heating power of about 900 watts up to a pre-scheduled time shutdown (32 days after switching the reactor with fuel). The reactor was off by gradually decreasing the power of the electric heating. Until that time the reactor operation occurred without a noticeable reduction of the power of heat generation that indicates that the service life of the reactor after 32 days operation was not exhausted.

The measurements showed that the heat dissipation of the reactor is much more energy consumption. When power consumption of 790 watts in the first 10 days of operation of the reactor, the additive to the power consumed, 
on average, is 1650 watts. After increasing the power consumption to 900 watts the value of supplements in an average of 2300 watts.

The report made the calculation of the energy produced during the reactor operation in excess of the consumed electric power: 1.6 MW h or $5800 \mathrm{MJ}$. Attributing this value to the mass of fuel $1 \mathrm{~g}$, we estimate the density of energy release $1.6 \cdot 109 \mathrm{~W} \cdot \mathrm{h} / \mathrm{kg}=5.8 \cdot 106 \mathrm{MJ} / \mathrm{kg}$. It is in hundreds of thousands times more than what can be obtained with the combustion of petroleum products.

After cooling of reactor the hole on the tip was opened, spent fuel extracted, poured into a container and checked for radioactivity similarly to testing of the fuel before loading. After that, the spent fuel has been subjected to various tests.

The analysis of the elemental and isotopic composition of the fuel was made by three independent groups of researchers specializing in the application of various techniques. Were used scanning electron microscope (SEM) to study the surface morphology of the fuel powder. Were using methods of x-ray photoelectron spectroscopy (XPS), dispersive $\mathrm{x}$-ray spectroscopy (EDS), time-of-flight mass spectrometry of secondary ions (ToFSIMS), mass spectrometry with inductively coupled plasma (ICP-MS) and atomic emission spectroscopy (ICP-AES). The application of the complex of these methods allows to give quite extensive information about the properties of fuel before and after operation of the reactor.

The conducted analyzes allowed to draw the following conclusions.

The original fuel is mainly composed of nickel powder in the form of pellets the size of a few microns, having a natural isotopic composition. In addition to the nickel in the fuel is detected admixture of $\mathrm{Li}, \mathrm{Al}, \mathrm{Fe}$ and $\mathrm{H}$. The analysis of ICP-AES showed that the ratio of the contents of $\mathrm{Li}$ and $\mathrm{Al}$ corresponds to the molecule of lithium aluminum hydride, $\mathrm{Li}\left[\mathrm{AlH}_{4}\right]$. This component is likely used to produce free hydrogen by heating. In addition, EDS and XPS analyses revealed the presence of $\mathrm{O}$ and $\mathrm{C}$. The analysis of the ToF-SIMS showed the presence of protium, but did not notice the presence of deuterium. The amount of most elements differs greatly in different granules.

The spent fuel has granules of a different kind than the initial fuel. The elemental and isotopic composition of granules is different, however, it is obvious that the isotopic composition of $\mathrm{Li}$ and $\mathrm{Ni}$ in spent fuel is radically different from the measured isotopic composition of the initial fuel (Table 1).

Although the results of measurements of the isotope composition by the two methods do not completely coincide, the following conclusions can be drawn.

1. The ratio of isotopes of lithium and nickel in the original fuel is within the possible error does not differ from the natural.

2. In the spent fuel the relative content of ${ }^{6} \mathrm{Li}$ increased significantly and the content of ${ }^{7} \mathrm{Li}$ decreased.

3. In spent fuel, the content of all isotopes of nickel, except ${ }^{62} \mathrm{Ni}$, has decreased very much. The content of this isotope increased from 3.6\% to $99 \%$.

Such a strong change in the isotopic ratio of lithium and nickel, after 32 days of reactor work suggests that the registered anomalously large energy release is associated with changes at the nuclear level.

Table 1.

The isotopic composition of lithium and nickel in the source and spent fuel (\%), measured by methods ToF-SIMS and ICP-MS, as well as the natural ratio of isotopes in these elements

\begin{tabular}{|c|c|c|c|c|c|}
\hline & \multicolumn{2}{|c|}{ Initial fuel } & \multicolumn{2}{c|}{ Spent fuel } & Nature \\
\hline & ToF-SIMS & ICP-MS & ToF-SIMS & ICP-MS & \\
\hline${ }^{6} \mathrm{Li}$ & 8.6 & 5.9 & 92.1 & 57.5 & 7.5 \\
\hline${ }^{7} \mathrm{Li}$ & 91.4 & 94.1 & 7.9 & 42.5 & 92.5 \\
\hline${ }^{58} \mathrm{Ni}$ & 67 & 65.9 & 0.8 & 0.3 & 68.1 \\
\hline${ }^{60} \mathrm{Ni}$ & 26.3 & 27.6 & 0.5 & 0.3 & 26.2 \\
\hline${ }^{61} \mathrm{Ni}$ & 1.9 & 1.3 & 0.0 & 0.0 & 1.8 \\
\hline${ }^{62} \mathrm{Ni}$ & 3.9 & 4.2 & 98.7 & 98.3 & 3.6 \\
\hline${ }^{64} \mathrm{Ni}$ & 1.0 & & 0.0 & & 0.5 \\
\hline
\end{tabular}


To check the possible ionizing radiation were used scintillation detectors and Geiger counters, as well as thermoluminescent dosimeters. This allowed registration of alpha, beta, gamma radiations and neutrons near working reactor. In addition, it was measured the radioactivity of the fuel before the filling of the reactor and after completion of work. None of these devices had not registered the difference from the background during operation of the reactor or in the study of the initial and spent fuel.

\section{ATTEMPTS TO REPRODUCE ROSSI REACTOR}

Researches in the field of cold nuclear transmutations - pretension on experiments, showing the path to acquiring fundamentally new knowledge and discovery new possibilities for the human community. But from the point of view of established scientific knowledge, the nuclear transmutation at low energies, without nuclear radiation, is absolutely impossible. In such circumstances, the first thing need to do is to make sure that such unusual results - not the result of errors or deliberate falsifications. Even the most strict and fair examination is insufficient. It is necessary to independently reproduce these results by other people, in other laboratories, with other equipment.

After the publication of the report of experts on the work of last version of Rossi reactor, its structure became in general clear, and it was finally possible to reproduce it. This reactor, in fact, is ceramic tube, sealed of heatresistant cement, in which there is the nickel powder with the addition of lithium aluminum hydride $\mathrm{Li}\left[\mathrm{AlH}_{4}\right]$. To initiate the process, the tube has slowly heated to a temperature of $1200-1400^{\circ} \mathrm{C}$. First of all, when heated, occurs decomposition of lithium aluminum hydride. The liberated hydrogen cleans the surface of nickel from oxides. After that, the hydrogen starts to dissolve in the nickel. After reaching a sufficiently high temperature in nickel with dissolved in it hydrogen, lithium and aluminum, begins a process with a high heat release.

Realizing this, many researchers around the world began to try to reproduce the heatgenerator Rossi. But it was not as simple task as it seems at first glance. Need to find a constructive materials that can withstand a corrosive environment at high temperature and elevated pressure, and to provide sealing. Need heaters, which operate at high temperature continuously. It is necessary to provide temperature measurement of the order of $1400^{\circ} \mathrm{C}$, and to work out the control techniques of power of operating reactor.

A report on the first successful test of the Rossi reactor analogue was made as early as December 2014. [25]. For the manufacture of reactor used a tube of corundum ceramics 120 $\mathrm{mm}$ in length, an outer diameter of $10 \mathrm{~mm}$ and an inner diameter of $5 \mathrm{~mm}$ (Fig. 4). On tube is wound an electric heater of heat-resistant wire. Inside the tube is $1 \mathrm{~g}$ powder of nickel, mixed with $0.1 \mathrm{~g}$ of lithium aluminum hydride. On the outer surface tube there is thermocouple. The ends of the tube are sealed with heat-resistant cement. The same cement covers the whole surface of the reactor.

As the power source for the heater was used the transformer with switched windings. Switching was both manual and automatic
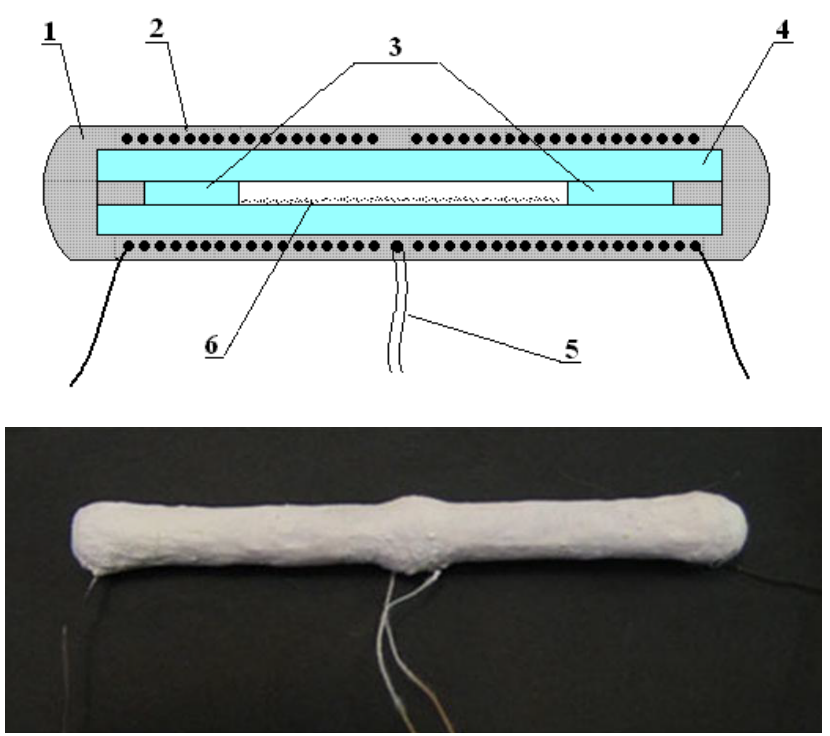

Fig. 4. The scheme of Rossi's reactor analogue [26]: 1 - cement, 2 - electric heater, 3 - ceramic bungs, 4 - ceramic tube, 5 thermocouple, 6-powder of $\mathrm{Ni}+\mathrm{LiAlH}_{4}$. Below - foreign view. 
with using the regulator controlled by the thermocouple signal. Heating up to operating temperature lasted 10-12 hours. For measuring consumption of electricity are used the voltmeter and the ammeter, and the meter, allowing you to transfer data to the computer. To control the level of radiation used Geiger counter SI-8B, the dosimeter DK-02 and neutron activation technique, using indium.

The method used to measuring the power of heat generation, based on the readings of thermal imagers [24], used by experts for testing the Rossi reactor is too complicated. In this experiment used a methodology based on the amount of evaporating water. This technique worked and repeatedly verified in various experiments. The reactor is in closed metal vessel (Fig. 5). This vessel is immersed in water. Part of water goes away as steam. By measuring the loss of water, by a known value of heat of vaporization (2260 $\mathrm{kJ} / \mathrm{kg}$ ) is easy to calculate the separated heat. A correction for heat loss through insulation can be calculated using the cooling rate after shutdown of the reactor.

A detailed description of the progress of the experiments and of technic of results processing can be found in [25]. Here are only a summary of the results obtained in experiments conducted in December 2014 and January 2015 (Table 2). In addition to the experiments with reactors, which loaded with a mixture of $\mathrm{Ni}+$

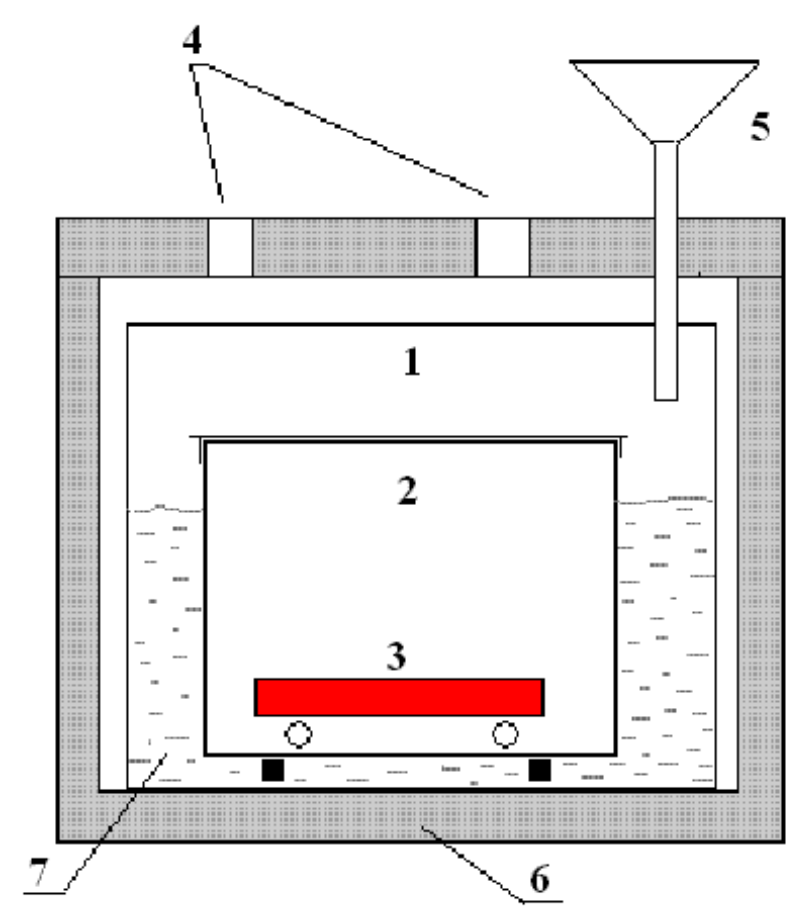

Fig. 5. The scheme of the calorimeter with evaporating water: 1 - vessel for the water, 2 - vessel for the reactor, 3 reactor, 4 holes for the escape of steam, 5-funnel for adding water, 6- heat insulation, 7 - water.

$\mathrm{Li}\left[\mathrm{AlH}_{4}\right]$, were carried out experiments with models of the reactor without fuel.

A significant excess of released heat energy over the absorbed electrical energy was observed only in reactors with fuel at temperatures about $1080^{\circ} \mathrm{C}$ and above. In cases with models reactor, as well as with reactors with fuel at a temperature below $1080^{\circ} \mathrm{C}$, the ratio of the emitted heat energy to absorbed electric power close to 1.

Table 2.

The ratio of emitted heat to electricity consumed (COP)

in the experiments in December 2014 and January 2015

\begin{tabular}{|l|c|c|c|c|c|}
\hline \multicolumn{6}{|c|}{ Reactor with fuel } \\
\hline Date & Temper. & Duration & Consump. & Gener. & COP \\
\hline & ${ }^{\circ} \mathrm{C}$ & $\min$ & $\mathrm{W}$ & $\mathrm{W}$ & \\
\hline 20.12 .2014 & 970 & 38 & 301 & 297 & 0.99 \\
\hline 20.12 .2014 & 1150 & 50 & 395 & 758 & 1.92 \\
\hline 20.12 .2014 & 1290 & 40 & 499 & 1365 & 2.74 \\
\hline 04.01 .2015 & 940 & 131 & 304 & 305 & 1.00 \\
\hline 04.01 .2015 & 1020 & 75 & 377 & 407 & 1.08 \\
\hline 10.01 .2015 & 1080 & 73 & 161 & 281 & 1.77 \\
\hline 18.01 .2015 & 800 & 90 & 308 & 293 & 0.95 \\
\hline 18.01 .2015 & 1080 & 38 & 78 & 135 & 1.73 \\
\hline
\end{tabular}

\begin{tabular}{|l|c|c|c|c|c|}
\hline \multicolumn{7}{|c|}{ Reactor without fuel } \\
\hline Date & Temper. & Duration & Consump. & Gener. & COP \\
\hline & ${ }^{\circ} \mathrm{C}$ & $\min$ & $\mathrm{W}$ & $\mathrm{W}$ & \\
\hline 02.01 .2015 & 210 & 56 & 211 & 227 & 1.07 \\
\hline 02.01 .2015 & 470 & 88 & 433 & 414 & 0.95 \\
\hline 02.01 .2015 & 1050 & 16 & 328 & 1035 & 1.12 \\
\hline 21.01 .2015 & 1000 & 69 & 297 & 296 & 1.00 \\
\hline 21.01 .2015 & 1080 & 43 & 306 & 297 & 0.97 \\
\hline 28.01 .2015 & 900 & 65 & 955 & 105 & 1.08 \\
\hline 28.01 .2015 & 1100 & 66 & 116 & 116 & 1.00 \\
\hline 28.01 .2015 & 1200 & 50 & 151 & 147 & 0.97 \\
\hline
\end{tabular}


Thus, these experiments showed that a mixture of nickel and lithium aluminum hydride, with heated in hermetic ceramic tube to a temperature above $1080^{\circ} \mathrm{C}$, indeed, produces much more heat than it consumes. The level of ionizing radiations during reactor operation is not appreciably higher than the background indicators. The density of neutrons flux is not higher than 0.2 neutr. $/ \mathrm{cm}^{2} \mathrm{c}$.

Later it was created a lot of experimental installations, confirming the presence of excess heat generation in devices similar to the heat generator Rossi. In the paper [26] described 15 devices of this kind created in Russia, USA and China. In this article we will give a description of some of the many devices, created in our team.

\section{ESTIMATION OF POSSIBLE CHANGES IN THE ISOTOPE COMPOSITION OF FUEL}

We can estimate the possible changes in the isotopic composition of the fuel assuming that the excess heat release occurs as a result of nuclear transmutations in accordance with the law of conservation of energy. For example, in nickel, containing hydrogen, a nuclear reaction may occur

$$
{ }^{58} \mathrm{Ni}+{ }^{1} \mathrm{H}+2 \mathrm{e}-\rightarrow{ }^{59} \mathrm{Co}+10.32 \mathrm{MeV}
$$

Since $1 \mathrm{MJ}$ is equal to $6.3 \cdot 10^{18} \mathrm{MeV}$, about $6 \cdot 10^{17}$ nickel nuclei $(0.00006 \mathrm{~g})$ are consumed as a result of this reaction to release $1 \mathrm{MJ}$ of energy, and the same amount of cobalt is formed. Nickel-hydrogen reactors usually contain about $1 \mathrm{~g}$ of fuel. It is quite possible, using modern technology, to detect $0.00006 \mathrm{~g}$ of cobalt in $1 \mathrm{~g}$ nickel $(0.006 \%)$.

It is more difficult to detect changes in the isotopic ratios. Conventional mass spectral analyzers allow one to capture changes in isotopic ratios of elements of the order of $1 \%$. It is not possible to detect a change of the order of $0.01 \%$ that occurs when $1 \mathrm{MJ}$ of energy released into 1 $\mathrm{g}$ of fuel as a result of the reaction (1). To reduce the content of the isotope ${ }^{58} \mathrm{Ni}$ by $1 \%$, an excess energy of the order of $100 \mathrm{MJ}$ is necessary.

If the fuel contains lithium, a nuclear reaction is possible

$$
{ }^{7} \mathrm{Li}+{ }^{1} \mathrm{H} \rightarrow 2^{4} \mathrm{He}+17.35 \mathrm{MeV}
$$

As a result of this reaction, in a mixture of lithium isotopes (the natural mixture contains $92.6 \%$ of ${ }^{7} \mathrm{Li}$ and $7.4 \%$ of $\left.{ }^{6} \mathrm{Li}\right)$ the content of ${ }^{7} \mathrm{Li}$ decreases and, accordingly, the content of ${ }^{6} \mathrm{Li}$ increases. Suppose that all excess energy release is associated with reaction (2). To release $1 \mathrm{MJ}$ of energy, $4 \cdot 10^{177} \mathrm{Li}$ nuclei are required $\left(4.2 \cdot 10^{-6} \mathrm{~g}\right)$. A typical reactor with fuel mixture of lithiumaluminum hydride and nickel contains about 0.02 $\mathrm{g}$ of ${ }^{7} \mathrm{Li}$. Therefore, when $1 \mathrm{MJ}$ is released, only $0.02 \%{ }^{7} \mathrm{Li}$ is removed. It is almost impossible to detect such a change. With the release of 1000 MJ of energy, $20 \%$ of ${ }^{7} \mathrm{Li}$ is removed. This leads to an increase in the content of ${ }^{6} \mathrm{Li}$ from 7.4 to $10 \%$. This change is quite possible to detect, although not easy because of the small mass of the material available for analysis.

Thus, the appearance of nuclides that are absent in the initial fuel can be detected with excess energy of the order of $1 \mathrm{MJ}$ per gram of fuel. To reliably detect changes in the ratios of isotopes in elements that originally are a part of fuel, excess energy exceed $100 \mathrm{MJ} / \mathrm{g}$ is required. It is natural that a thorough analysis of the fuel of the GS3 reactor made by Alan Goldwater did not reveal any noticeable isotope changes, since the excess energy production in it was about $50 \mathrm{MJ} / \mathrm{g}[3,4]$. The excess energy production in the high-temperature heat-generator of Rossi, according to [1], was $5800 \mathrm{MJ} / \mathrm{g}$. This is quite sufficient for radical changes in the isotopic composition of both nickel and lithium. Further, we will present the results of an analysis of isotope changes in fuel and in structural materials that occurred in several nickel-hydrogen reactors created in our laboratory.

\section{REACTOR AP2}

Reactor AP2 [28] was charged with a fuel

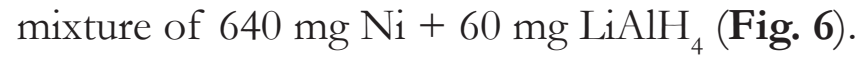




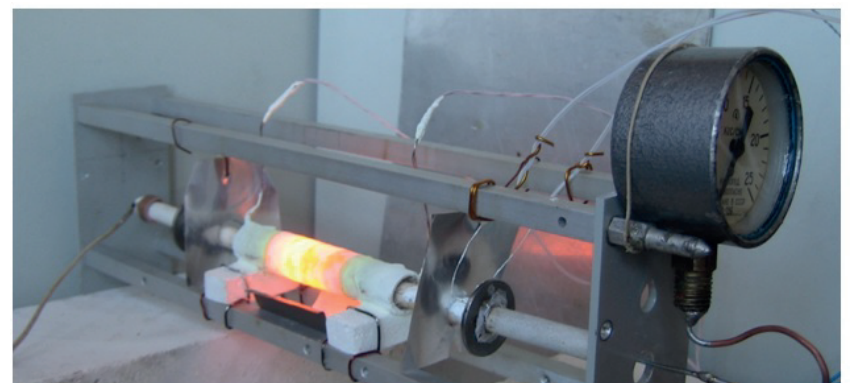

Fig. 6. Reactor AP2.

It worked from March 16 until March 22, 2015, and produced about $150 \mathrm{MJ}$ of excess heat.

Analyzes of fuel before and after the experiment were made using several methods in different organizations. The analysis of the elemental composition using an electron scanning microscope was made at the Prokhorov General Physics Institute, Russian Academy of Sciences and All-Russian Research Institute of Experimental Physics (VNIIEF, Sarov). Two fractions confidently differ in the fuel mixture measured before experiment: gray crystals and white granules. Gray crystals mainly contain $\mathrm{Al}, \mathrm{O}$, and $\mathrm{Cl}$. White granules consist of nickel with a small admixture of iron, aluminum and oxygen. In the fuel after the experiment, white molten and gray slag-like structures are visible. White structures contain mainly nickel with an admixture of Fe, Al, Cr, Mn, Si and O. Slaglike structures consist mainly of $\mathrm{Al}$ and $\mathrm{O}$.

Analysis of the elemental composition of the fuel before and after experiment using laser atomic emission spectrometer was made at the Kurnakov Institute of General and Inorganic Chemistry, Russian Academy of Sciences. It showed that the content of $\mathrm{K}$ and $\mathrm{Cr}$ increased tens of times after the experiment. The content of $\mathrm{Si}, \mathrm{Na}, \mathrm{Mg}, \mathrm{Ca}$, Ti, and V increased manifold. The content of $\mathrm{Al}, \mathrm{Ni}, \mathrm{Cl}, \mathrm{Mn}, \mathrm{Cu}, \mathrm{Zn}$ decreased. It should be noted, that this method of analysis, as well as analysis using a scanning electron microscope, provides information on the atomic composition only on the surface of the test substance.
Table 3. Analysis of AP2 reactor fuel by the ICP-MS method at Uppsala University (Sweden)

\begin{tabular}{|c|c|c|c|c|c|c|c|}
\hline$\%$ & ${ }^{6} \mathrm{Li}$ & ${ }^{7} \mathrm{Li}$ & ${ }^{58} \mathrm{Ni}$ & ${ }^{60} \mathrm{Ni}$ & ${ }^{61} \mathrm{Ni}$ & ${ }^{62} \mathrm{Ni}$ & ${ }^{64} \mathrm{Ni}$ \\
\hline Before & 7.4 & 92.6 & 68.1 & 26.2 & 1.14 & 3.63 & 0.93 \\
\hline After & 15.4 & 84.6 & 63.4 & 27.6 & 1.3 & 5.2 & 2.5 \\
\hline Nature & 7.6 & 92.4 & 68.0 & 26.2 & 1.14 & 3.71 & 0.93 \\
\hline
\end{tabular}

Analysis of the isotope composition of the fuel before and after the experiment in AP2 reactor was made using ICP-MS method, which gives information on the isotopic composition on average over the sample. Such analysis was made in Vernadsky Institute of Geochemistry and Analytical Chemistry of Russian Academy of Sciences. Total content of aluminum and lithium after the experiment decreased, while the relative content of ${ }^{6} \mathrm{Li}$ increased slightly. However this increase (by $0.5 \%$ ) fall within the range of possible measurement error. There are no significant changes in the isotopic composition of nickel.

The analysis of AP2 reactor fuel by the ICPMS method was also made at Uppsala University (Sweden). The results of these measurements are shown in Table 3.

According to these measurements, the relative content of ${ }^{6} \mathrm{Li}$ in the sample of spent fuel has more than doubled. Quite noticeable changes have occurred also in the ratio of nickel isotopes. These results differ from the results obtained in Vernadsky Institute of Geochemistry and Analytical Chemistry RAS. This difference can be explained, perhaps, by the unevenness of the changes in the sample volume. It should be noted that reliable results for lithium are difficult to obtain because of a very low concentration of lithium in spent fuel $(<0.01 \%)$.

\section{REACTOR PROTOK-6}

Reliable measurement of generated heat is a key challenge in creating devices, which prove the existence of excess heat generation. The technique with running water is considered the most accurate, so we used the flow-through calorimeter to measure the heat generation in the twelve reactors. This article describes one 


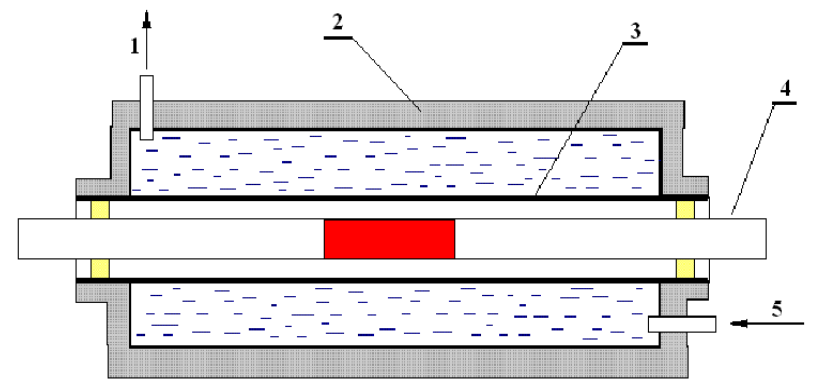

Fig. 7. Device flow-through calorimeter: 1 - flowing in water, 2 - insulation 3 - copper tube, 4 - reactor, 5 - flowing out water.

of them [29], who has worked for more than a month (Fig. 7).

We used a flow-through calorimeter in which the generated heat absorbed by the water which washed around the copper pipe, in which reactor is located. Power of heat generation is determined by the formula $\mathrm{W}=\mathrm{c}(\mathrm{dm} / \mathrm{dt})\left(\mathrm{T}-\mathrm{T}_{0}\right)(1+\alpha)$, where $\mathrm{c}$ is the specific heat of water, $(\mathrm{dm} / \mathrm{dt})$ is the mass of water flowing per second, $\alpha$ is the correction for heat loss, $\mathrm{T}_{0}$ is the temperature at the inlet to the calorimeter, $\mathrm{T}$ is the temperature at the outlet.

In Fig. 8 shows the structure of the reactor. The fuel $(1.8 \mathrm{~g}$ of nickel powder mixed with $0.2 \mathrm{~g}$ of lithium aluminum hydride) was located in a ceramic tube of length of $80 \mathrm{~mm}$, external diameter of 7.5 $\mathrm{mm}$, inner diameter of $5 \mathrm{~mm}$. On the tube is wound a spiral of tungsten wire $0.5 \mathrm{~mm}$ in diameter. In the tube is inserted the ceramic rods, which by centering washers holding the inner tube in the middle of the reactor. In the longitudinal hole of one of the rods inserted W-Re high temperature thermocouple, which measures the temperature of the fuel end. Another thermocouple (type K) controls

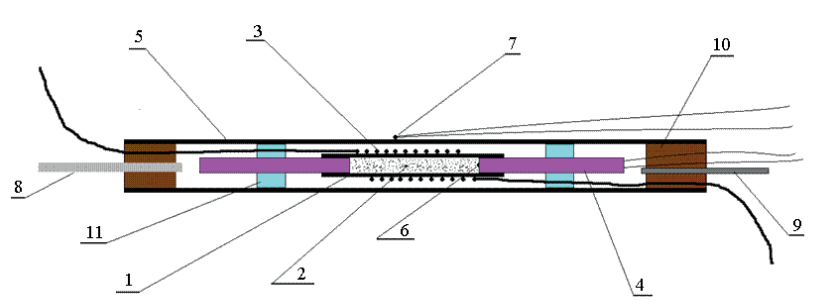

Fig. 8. Scheme of the "Protok- 6 " reactor: 1 - inner ceramic tube, 2 - fuel, 3 - heater W, 4 - ceramic rods, 5 - external ceramic tube, 6 - termokcouple $W$-Re, 7 - termocouple K, 8 tube for manometer, 9-pumping tube, 10 - sealant, 11-centering washers. the temperature of the outer surface of the outer ceramical tube. This tube has an outer diameter of $18 \mathrm{~mm}$ and inner $14 \mathrm{~mm}$. Due to the great length of the outer tube $(350 \mathrm{~mm})$ and the low thermal conductivity of ceramics during reactor operation, the temperature of its ends does not exceed $50^{\circ} \mathrm{C}$, which allows for sealing use the epoxy compound. Of the ends of the reactor, in addition to the wiring of the heater, metal tube goes out for connecting the manometer and the glass tube for pumping air.

The power supply to the reactor was carried out from the secondary winding of transformer capacity of 630 watts. The switch taps of the secondary winding allows you to set the desired heating power. The thermocouple that measures the temperature of the end fuel, is connected to the thermostat TRM-500, which keeps the heater on until the temperature reaches the set value, and disables it when exceeding a predetermined temperature. Heating power is measured by voltmeter and ammeter directly on the heater, and also by a power meter, installed on the inlet of the transformer. Mapping power on the heater with the power on the primary winding allows to determine the losses in the transformer and wires. This is necessary to amend the results of the measurements of pulses power consumption by electric meter, that is registering by a computer. In addition to energy consumption, the computer registers the temperature at the inlet and outlet of calorimeter, as well as information about water consumption coming from the flow meter.

To verify the device was used similar to the above described reactor, which does not contain fuel. These measurements showed that the deviation of the data of the calorimeter from the results of measurement of electric power does not exceed $3 \%$.

In the preparatory phase of measurements out of reactor, who was heated to $120^{\circ} \mathrm{C}$, by the roughing pump was pumped air, to remove residual water and other volatile contaminants. 


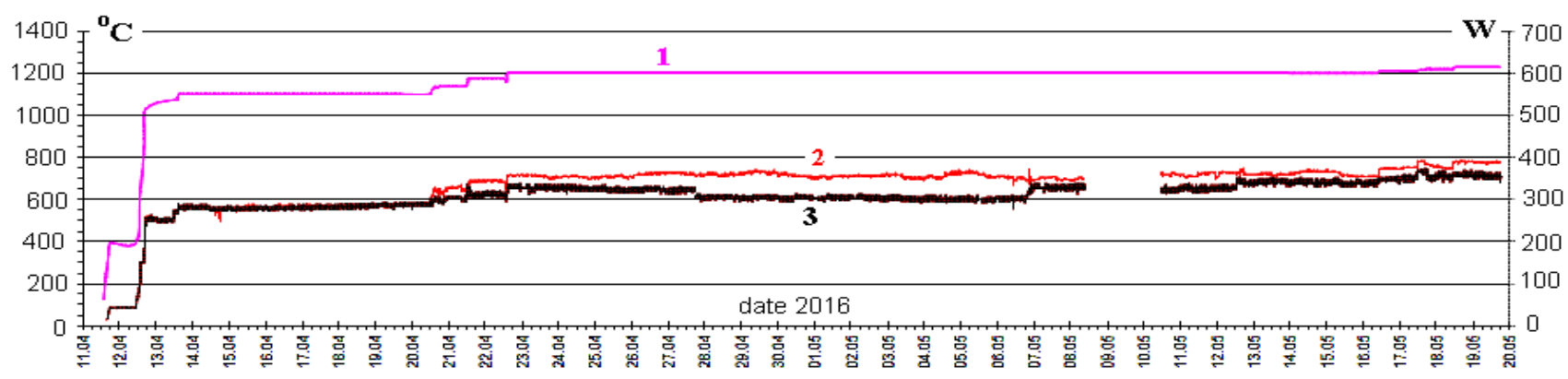

Fig. 9. Change of temperature (1), power heat generation (2) and of power of electrical heating (3) during operation of the reactor.

Next the vacuumed reactor was disconnected from the vacuum pump by melting in the flame of a gas burner glass tube connecting the reactor with a vacuum pump. Next as a result of heating the inner tube to a temperature of $180-200^{\circ} \mathrm{C}$ occurred the decomposition of lithium aluminum hydride, and the reactor was filled with hydrogen to a pressure of $4.25 \mathrm{bar}$. Then the temperature was increased to $400^{\circ} \mathrm{C}$ and kepted at this level for about 20 hours. By means of opening the valve located on the tube connecting the reactor pressure gage, the pressure was reduced to 0.4 bar. In the process of gradual increase in temperature after small increases of pressure at a temperature of $1100^{\circ} \mathrm{C}$, in despite of a further increase in the temperature, pressure began to fall and on the fourteenth day from the beginning of the experiment has become below atmospheric.

In Fig. 9 it is showen how varied during the 38 days from beginning to end of the experiment, the power of electrical heating, the temperature on the end of fuel and power heat generation, as measured by the calorimeter.

It is seen that at temperatures up to $1100^{\circ} \mathrm{C}$ power heat generation, measured by the calorimeter, almost equal to the power, emitted by the electric heater. Starting from a temperature of $1150^{\circ} \mathrm{C}$, the power heat generation is clearly higher of the power of the electric heater. Change of difference between the power of heat generation (excess capacity) and of capacity for energy consumption shown in Fig. 10. It is also shown how varied for the experiment, the power ratio of allocated heat to power consumed by the electric heater (COP).

It is seen that the emergence of excess power of about 30 watts, significantly exceeding the possible error of the measurements, occurred after reaching a temperature of $1150^{\circ} \mathrm{C}$. Approximately such excess capacity is produced at the beginning and with increasing temperature up to $1200^{\circ} \mathrm{C}$. But after 5 days without external intervention there was a sharp increase of excess power to 50-60 watts. 9 days after this occurred an equally sharp decrease

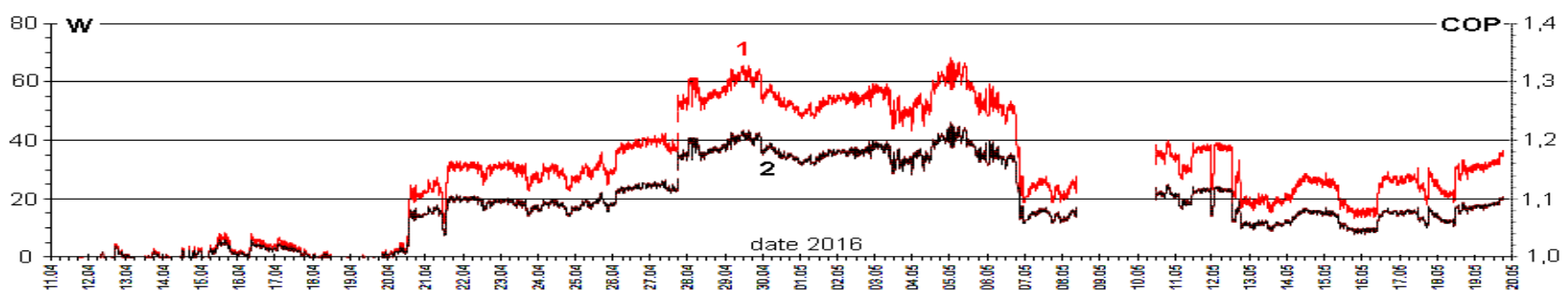

Fig. 10. Change of excess power (1) and ratio of the produced heat power to power consumed by the electric heater COP (2). 
to 20-30 watts. In the last week fluctuations in excess capacity within the limits of 15-30 W were observed with a period of about 2 days. A gradual increase in temperature up to $1230^{\circ} \mathrm{C}$ led to a rise in excess capacity of 35 watts, but the work in such mode through the day led to the exit of the reactor down due to burnout of the electric heater. For total time of the experiment was produced about $100 \mathrm{MJ}$ of excess heat.

After the experiment was over, the reactor was opened (Fig. 11). It was found that the inner surface of the outer tube near the heater was covered with

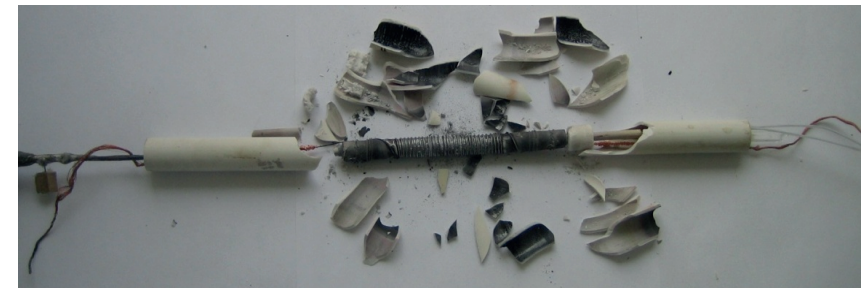

Fig. 11. Reactor "Protok-6" after opening.

lumpy gray glassy coating. The physical configuration of the inner tube and the heater winding was preserved. However, the changes inside were significant: a vitreous mass with inclusions of metal balls measuring about $0.1 \mathrm{~mm}$ was formed. Several

Table 4.

Relative content of isotopes (atomic \%) in fuel and near the core of the "Protok-6" reactor before and after reactor operation. Isotopes with a content $>0.1 \%$ are shown.

\begin{tabular}{|l|l|l|l|l|l|}
\hline \multicolumn{6}{|c|}{ Before reactor operation } \\
\hline \multicolumn{2}{|c|}{ Initial fuel } & \multicolumn{2}{c|}{ Ceramics } & \multicolumn{2}{c|}{ W wire } \\
\hline${ }^{7} \mathrm{Li}$ & 0.74 & ${ }^{23} \mathrm{Na}$ & 7.01 & ${ }^{23} \mathrm{Na}$ & 5.37 \\
\hline${ }^{23} \mathrm{Na}$ & 1.90 & ${ }^{24} \mathrm{Mg}$ & 1.61 & ${ }^{24} \mathrm{Mg}$ & 0.24 \\
\hline${ }^{24} \mathrm{Mg}$ & 0.12 & ${ }^{25} \mathrm{Mg}$ & 0.23 & ${ }^{27} \mathrm{Al}$ & 0.31 \\
\hline${ }^{27} \mathrm{Al}$ & 3.63 & ${ }^{26} \mathrm{Mg}$ & 0.28 & ${ }^{29} \mathrm{Si}$ & 1.88 \\
\hline${ }^{29} \mathrm{Si}$ & 1.04 & ${ }^{27} \mathrm{Al}$ & 65.05 & ${ }^{31} \mathrm{P}$ & 0.18 \\
\hline${ }^{39} \mathrm{~K}$ & 1.60 & ${ }^{29} \mathrm{Si}$ & 1.55 & ${ }^{39} \mathrm{~K}$ & 6.09 \\
\hline${ }^{44} \mathrm{Ca}$ & 0.28 & ${ }^{31} \mathrm{P}$ & 0.16 & ${ }^{44} \mathrm{Ca}$ & 1.06 \\
\hline${ }^{45} \mathrm{Sc}$ & 0.22 & ${ }^{39} \mathrm{~K}$ & 8.36 & ${ }^{45} \mathrm{Sc}$ & 0.80 \\
\hline${ }^{51} \mathrm{~V}$ & 0.68 & ${ }^{44} \mathrm{Ca}$ & 0.94 & ${ }^{54} \mathrm{Cr}$ & 0.40 \\
\hline${ }^{53} \mathrm{Cr}$ & 0.22 & ${ }^{45} \mathrm{Sc}$ & 0.61 & ${ }^{56} \mathrm{Fe}$ & 10.46 \\
\hline${ }^{55} \mathrm{Mn}$ & 0.17 & ${ }^{48} \mathrm{Ti}, \mathrm{Ca}$ & 0.15 & ${ }^{182} \mathrm{~W}$ & 18.50 \\
\hline${ }^{56} \mathrm{Fe}$ & 0.99 & ${ }^{54} \mathrm{Cr}$ & 0.41 & ${ }^{183} \mathrm{~W}$ & 9.52 \\
\hline${ }^{58} \mathrm{Fe}, \mathrm{Ni}$ & 65.91 & ${ }^{56} \mathrm{Fe}$ & 10.00 & ${ }^{184} \mathrm{~W}$ & 21.48 \\
\hline${ }^{60} \mathrm{Ni}$ & 23.58 & ${ }^{58} \mathrm{Fe}, \mathrm{Ni}$ & 0.15 & ${ }^{186} \mathrm{~W}, \mathrm{Os}$ & 21.29 \\
\hline${ }^{61} \mathrm{Ni}$ & 1.10 & ${ }^{89} \mathrm{Y}$ & 0.25 & ${ }^{200} \mathrm{Hg}$ & 0.20 \\
\hline${ }^{62} \mathrm{Ni}$ & 3.63 & ${ }^{90} \mathrm{Zr}$ & 0.44 & ${ }^{202} \mathrm{Hg}$ & 0.21 \\
\hline${ }^{64} \mathrm{Ni}, \mathrm{Zn}$ & 1.24 & ${ }^{92} \mathrm{Sr}, \mathrm{Mo}$ & 0.16 & ${ }^{198} \mathrm{Hg}$ & 0.21 \\
\hline${ }^{66} \mathrm{Zn}$ & 0.16 & ${ }^{94} \mathrm{Sr}, \mathrm{Mo}$ & 0.16 & & \\
\hline${ }^{68} \mathrm{Zn}$ & 0.12 & ${ }^{138} \mathrm{Ba}, \mathrm{Ce}$ & 0.33 & & \\
\hline${ }^{79} \mathrm{Br}$ & 0.13 & ${ }^{206} \mathrm{~Pb}$ & 0.13 & & \\
\hline${ }^{81} \mathrm{Br}$ & 0.12 & ${ }^{208} \mathrm{~Pb}$ & 0.29 & & \\
\hline${ }^{138} \mathrm{BaLaCe}$ & 0.25 & & & & \\
\hline${ }^{206} \mathrm{~Pb}$ & 0.32 & & & & \\
\hline${ }^{208} \mathrm{~Pb}$ & 0.25 & & & & \\
\hline & 0.69 & & & & \\
\hline
\end{tabular}

\begin{tabular}{|c|c|c|c|c|c|c|c|}
\hline \multicolumn{8}{|c|}{ After reactor operation } \\
\hline \multicolumn{2}{|c|}{$\begin{array}{l}\text { Metal ball } \\
\text { in spent fuel }\end{array}$} & \multicolumn{2}{|c|}{$\begin{array}{l}\text { Coating on } \\
\text { inner surface } \\
\text { of outer tube }\end{array}$} & \multicolumn{4}{|c|}{$\begin{array}{l}\text { Substance appeared between } \\
\text { inner and outer tubes }\end{array}$} \\
\hline${ }^{11} \mathrm{Ba}$ & 0.19 & ${ }^{23} \mathrm{Na}$ & 1.56 & ${ }^{11} \mathrm{~B}$ & 0.44 & ${ }^{75} \mathrm{As}$ & 0.43 \\
\hline${ }^{23} \mathrm{Na}$ & 5.07 & ${ }^{24} \mathrm{Mg}$ & 1.16 & ${ }^{23} \mathrm{Na}$ & 14.70 & ${ }^{76} \mathrm{Ge}, \mathrm{Se}$ & 0.16 \\
\hline${ }^{24} \mathrm{Mg}$ & 0.21 & ${ }^{25} \mathrm{Mg}$ & 0.16 & ${ }^{24} \mathrm{Mg}$ & 0.82 & ${ }^{77} \mathrm{Se}$ & 0.17 \\
\hline${ }^{27} \mathrm{Al}$ & 0.22 & ${ }^{26} \mathrm{Mg}$ & 0.17 & ${ }^{26} \mathrm{Mg}$ & 0.15 & ${ }^{79} \mathrm{Br}$ & 0.97 \\
\hline${ }^{29} \mathrm{Si}$ & 3.94 & ${ }^{27} \mathrm{Al}$ & 0.23 & ${ }^{27} \mathrm{Al}$ & 0.92 & ${ }^{81} \mathrm{Br}$ & 1.03 \\
\hline${ }^{31} \mathrm{P}$ & 0.14 & ${ }^{29} \mathrm{Si}$ & 0.77 & ${ }^{29} \mathrm{Si}$ & 9.37 & ${ }^{90} \mathrm{Zr}$ & 0.16 \\
\hline${ }^{39} \mathrm{~K}$ & 3.51 & ${ }^{39} \mathrm{~K}$ & 0.86 & ${ }^{31} \mathrm{P}$ & 0.32 & ${ }^{116} \mathrm{In}, \mathrm{Sn}$ & 0.26 \\
\hline${ }^{43} \mathrm{Ca}$ & 0.14 & ${ }^{44} \mathrm{Ca}$ & 0.71 & ${ }^{39} \mathrm{~K}$ & 9.89 & ${ }^{120} \mathrm{Sn}, \mathrm{Te}$ & 0.12 \\
\hline${ }^{44} \mathrm{Ca}$ & 1.08 & ${ }^{45} \mathrm{Sc}$ & 0.24 & ${ }^{43} \mathrm{Ca}$ & 0.35 & ${ }^{127} \mid$ & 0.15 \\
\hline${ }^{45} \mathrm{Sc}$ & 0.91 & ${ }^{51} \mathrm{~V}$ & 0.10 & ${ }^{44} \mathrm{Ca}$ & 2.15 & ${ }^{138} \mathrm{Ba}, \mathrm{La}, \mathrm{Ce}$ & 0.36 \\
\hline${ }^{51} \mathrm{~V}$ & 1.56 & ${ }^{52} \mathrm{Cr}$ & 0.57 & ${ }^{45} \mathrm{Sc}$ & 1.95 & ${ }^{140} \mathrm{Ce}$ & 6.54 \\
\hline${ }^{52} \mathrm{Cr}$ & 0.14 & ${ }^{53} \mathrm{Cr}$ & 0.10 & ${ }^{48} \mathrm{TI}, \mathrm{Ca}$ & 0.13 & ${ }^{142} \mathrm{Ce}, \mathrm{Nd}$ & 0.85 \\
\hline${ }^{53} \mathrm{Cr}$ & 0.51 & ${ }^{54} \mathrm{Cr}$ & 1.17 & ${ }^{51} \mathrm{~V}$ & 6.08 & ${ }^{182} \mathrm{~W}$ & 3.50 \\
\hline${ }^{54} \mathrm{Cr}$ & 0.46 & ${ }^{56} \mathrm{Fe}$ & 19.10 & ${ }^{52} \mathrm{Cr}$ & 0.48 & ${ }^{183} \mathrm{~W}$ & 1.77 \\
\hline${ }^{55} \mathrm{Mn}$ & 0.14 & ${ }^{57} \mathrm{Fe}$ & 0.45 & ${ }^{53} \mathrm{Cr}$ & 2.07 & ${ }^{184} \mathrm{~W}$, Os & 4.09 \\
\hline${ }^{56} \mathrm{Fe}$ & 7.36 & ${ }^{58} \mathrm{Fe}, \mathrm{Ni}$ & 32.31 & ${ }^{54} \mathrm{Cr}$ & 0.61 & ${ }^{186} \mathrm{~W}$, Os & 3.82 \\
\hline${ }^{57} \mathrm{Fe}$ & 0.18 & ${ }^{59} \mathrm{Co}$ & 0.40 & ${ }^{55} \mathrm{Mn}$ & 0.28 & ${ }^{206} \mathrm{~Pb}$ & 0.21 \\
\hline${ }^{58} \mathrm{Fe}, \mathrm{Ni}$ & 45.07 & ${ }^{60} \mathrm{Ni}$ & 13.93 & ${ }^{56} \mathrm{Fe}$ & 6.48 & ${ }^{207} \mathrm{~Pb}$ & 0.19 \\
\hline${ }^{59} \mathrm{Co}$ & 19.81 & ${ }^{61} \mathrm{Ni}$ & 0.68 & ${ }^{57} \mathrm{Fe}$ & 0.18 & ${ }^{208} \mathrm{~Pb}$ & 0.49 \\
\hline${ }^{60} \mathrm{Ni}$ & 0.86 & ${ }^{62} \mathrm{Ni}$ & 2.10 & ${ }^{58} \mathrm{Fe}, \mathrm{Ni}$ & 8.25 & & \\
\hline${ }^{61} \mathrm{Ni}$ & 2.97 & ${ }^{64} \mathrm{Ni}, \mathrm{Zn}$ & 5.06 & ${ }^{60} \mathrm{Ni}$ & 3.30 & & \\
\hline${ }^{62} \mathrm{Ni}$ & 0.14 & ${ }^{66} \mathrm{Zn}$ & 2.88 & ${ }^{61} \mathrm{Ni}$ & 0.15 & & \\
\hline${ }^{64} \mathrm{Ni}, \mathrm{Zn}$ & 1.62 & ${ }^{67} \mathrm{Zn}$ & 0.47 & ${ }^{62} \mathrm{Ni}$ & 0.54 & & \\
\hline${ }^{66} \mathrm{Zn}$ & 0.52 & ${ }^{68} \mathrm{Zn}$ & 2.02 & ${ }^{63} \mathrm{Cu}$ & 0.17 & & \\
\hline${ }^{68} \mathrm{Zn}$ & 0.40 & ${ }^{88} \mathrm{Sr}$ & 0.11 & ${ }^{64} \mathrm{Ni}, \mathrm{Zn}$ & 1.48 & & \\
\hline${ }^{75} \mathrm{As}$ & 0.15 & ${ }^{115} \mathrm{In}, \mathrm{Sc}$ & 0.13 & ${ }^{66} \mathrm{Zn}$ & 0.81 & & \\
\hline${ }^{79} \mathrm{Br}$ & 0.35 & ${ }^{140} \mathrm{Ce}$ & 0.37 & ${ }^{67} \mathrm{Zn}$ & 0.15 & & \\
\hline${ }^{81} \mathrm{Br}$ & 0.36 & ${ }^{182} \mathrm{~W}$ & 2.81 & ${ }^{68} \mathrm{Zn}$ & 0.63 & & \\
\hline${ }^{138} \mathrm{Ba}, \mathrm{La}, \mathrm{Ce}$ & 0.14 & ${ }^{183} \mathrm{~W}$ & 1.54 & & & & \\
\hline${ }^{184} \mathrm{~W}$, Os & 0.12 & ${ }^{184} \mathrm{~W}$, Os & 3.52 & & & & \\
\hline${ }^{208} \mathrm{~Pb}$ & 0.17 & ${ }^{186} \mathrm{~W}$, Os & 3.24 & & & & \\
\hline
\end{tabular}


balls had a diameter of up to $1 \mathrm{~mm}$. At the ends of the filling, the fuel took the form of a sintered mass containing small metal balls. Furthermore, powder from the inner tube poured out. Using a magnet, a fraction was extracted from this powder consisting of filaments with a transverse dimension of about $0.1 \mathrm{~mm}$ and length up to $5 \mathrm{~mm}$.

Several samples were subjected to massspectroscopic analysis at Vernadsky Institute of Geochemistry and Analytical Chemistry RAS using the ICP-MS method. The following were investigated: the initial fuel mixture, the metal ball from the spent fuel, the fuel at the edge of the filling, the substance accumulated between the inner and outer tubes, and the coating on the inner surface of the outer tube. Due to the large amount of information received, it is not possible to present it completely. Partially, the results of the analysis are shown in Table 4 . In addition to the data for samples recovered from the reactor after its operation, information is given on the content of isotopes in the fuel, as well as in the ceramic and tungsten wire, before the experiment. This information is important, since the appearance of new elements can be associated not with transmutations, but with migration from structural materials, which is quite possible at high temperatures. Unfortunately, the ICP-MS method can not determine the content of isotopes with masses of 1-5, 12-22, 32, including isotopes of carbon, oxygen, nitrogen, fluorine and sulfur.

The obvious result is an increase in the content of many nuclides in comparison with their content in the initial fuel and structural materials. The exception is lithium (decrease in about 100 times) and aluminum in fuel (decrease in more than 10 times). We note a particularly great increase in the presence of boron, iron, gallium, cerium, zirconium, strontium and bismuth. The most significant anomalies are found in the powder accumulated in the space between the inner and outer tubes. Especially great amount of ${ }^{140} \mathrm{Ce}$ appeared: $6.3 \%$ (in the initial fuel $<0.0001 \%$ ). A significant amount of
Table 5.

The ratio of nickel isotopes in fuel and near the core of the "Protok-6" reactor before and after the experiment.

\begin{tabular}{|l|c|c|c|c|c|}
\hline \multicolumn{1}{|c|}{$\%$} & ${ }^{58} \mathrm{Ni}$ & ${ }^{60} \mathrm{Ni}$ & ${ }^{61} \mathrm{Ni}$ & ${ }^{62} \mathrm{Ni}$ & ${ }^{64} \mathrm{Ni}$ \\
\hline Initial fuel & 65.78 & 27.74 & 1.29 & 4.28 & 0.91 \\
\hline Metal ball & 65.00 & 28.57 & 1.24 & 4.29 & 0.91 \\
\hline Fuel at edge & 65.58 & 27.88 & 1.27 & 4.36 & 0.91 \\
\hline Coating on ceramics & 65.32 & 28.16 & 1.37 & 4.24 & 0.91 \\
\hline Powder between tubes & 66.74 & 26.71 & 1.23 & 4.41 & 0.91 \\
\hline Natural ratio & 68.27 & 26.1 & 1.13 & 3.59 & 0.91 \\
\hline
\end{tabular}

tungsten found in the samples after being inside the reactor is probably due to the migration of this element from the incandescent tungsten coil.

The investigation of possible changes in the isotopic composition of lithium and nickel is of great interest. Unfortunately, the very low content of lithium in the samples after experiment did not allow us to make reliable measurements. The results obtained for nickel are presented in the Table 5. Since the data on ${ }^{64} \mathrm{Ni}$ is unreliable due to the uncontrolled additive of ${ }^{64} \mathrm{Zn}$, when compiling the table, the value from the reference book [30] was used for the ${ }^{64} \mathrm{Ni}$ fraction. Since this fraction is small, such an assumption can change the fractions of the remaining isotopes only slightly.

It can be seen that the data for the various samples studied differ somewhat from the natural ratio [30], but differ insignificantly between different measurements. A noticeable increase in the ${ }^{62} \mathrm{Ni}$ fraction, due to a decrease in the fraction of the remaining isotopes, that was found in the experiment in Lugano [1, 2] was not observed in any of the samples studied. It is possible that the effect is not visible due to the fact that the excess energy production in Lugano experiment was 60 times greater than in the described one.

\section{REACTOR VV3}

Reactor VV3 (Fig. 12) differs from the "Protok $6 "$ reactor with a different heater design and
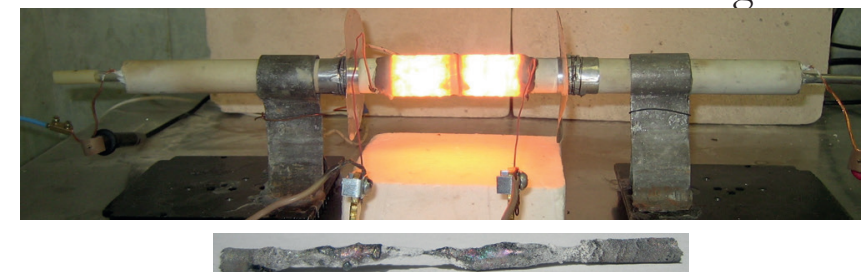

Fig. 12. Reactor VV3 and spent fuel extracted from it. 
Table 6. Isotope content (atomic \%) in the reactor fuel "VV3" before and after reactor operation. Isotopes with a content $>0.1 \%$ are shown.

\begin{tabular}{|c|c|c|c|c|c|c|c|}
\hline \multicolumn{8}{|c|}{ Fuel in the reactor VV3 } \\
\hline \multirow{2}{*}{\multicolumn{2}{|c|}{$\begin{array}{c}\text { Before } \\
\text { Initial fuel }\end{array}$}} & \multicolumn{6}{|c|}{ After } \\
\hline & & \multicolumn{2}{|c|}{ Surface } & \multicolumn{2}{|c|}{ Surface } & \multicolumn{2}{|c|}{ Deep layer } \\
\hline${ }^{23} \mathrm{Na}$ & 2.61 & ${ }^{10} \mathrm{~B}$ & 0.15 & ${ }^{75} \mathrm{As}$ & \begin{tabular}{|l|}
0.17 \\
\end{tabular} & ${ }^{10} \mathrm{~B}$ & 0.14 \\
\hline${ }^{24} \mathrm{Mg}$ & 0.15 & ${ }^{11} \mathrm{~B}$ & 0.67 & ${ }^{79} \mathrm{Br}$ & \begin{tabular}{|l|}
0.11 \\
\end{tabular} & ${ }^{11 B}$ & 0.66 \\
\hline${ }^{27} \mathrm{Al}$ & 2.93 & ${ }^{24} \mathrm{Mg}$ & 1.50 & ${ }^{81} \mathrm{Br}$ & \begin{tabular}{|l|}
0.21 \\
\end{tabular} & ${ }^{23} \mathrm{Na}$ & 3.72 \\
\hline${ }^{29} \mathrm{Si}$ & 1.22 & ${ }^{25} \mathrm{Mg}$ & 0.12 & ${ }^{88} \mathrm{Sr}$ & 0.23 & ${ }^{27} \mathrm{Al}$ & 1.02 \\
\hline${ }^{39} \mathrm{~K}$ & 2.52 & ${ }^{26} \mathrm{Mg}$ & 0.27 & ${ }^{90 \mathrm{Zr}}$ & 0.20 & ${ }^{28} \mathrm{Si}$ & 0.25 \\
\hline${ }^{44} \mathrm{Ca}$ & 0.44 & ${ }^{27} \mathrm{Al}$ & 1.14 & ${ }^{107} \mathrm{Ag}$ & 1.13 & ${ }^{51} \mathrm{~V}$ & 2.14 \\
\hline${ }^{45} \mathrm{Sc}$ & 0.34 & ${ }^{28} \mathrm{Si}$ & 0.54 & ${ }^{109} \mathrm{Ag}$ & \begin{tabular}{|l|l}
2.01 \\
\end{tabular} & ${ }^{52} \mathrm{Cr}$ & 0.30 \\
\hline${ }^{51} \mathrm{~V}$ & 0.55 & ${ }^{44} \mathrm{Ca}$ & 0.16 & ${ }^{127} \mathrm{I}$ & \begin{tabular}{|l|l}
0.43 \\
\end{tabular} & ${ }^{53} \mathrm{Cr}$ & 0.73 \\
\hline${ }^{53} \mathrm{Cr}$ & 0.18 & ${ }^{45} \mathrm{Sc}$ & 0.18 & ${ }^{140} \mathrm{Ce}$ & 0.72 & ${ }^{54} \mathrm{Cr}$ & 0.21 \\
\hline${ }^{55} \mathrm{Mn}$ & 0.14 & ${ }^{51} \mathrm{~V}$ & 2.41 & ${ }^{182} \mathrm{~W}$ & \begin{tabular}{|l}
3.34 \\
\end{tabular} & ${ }^{56} \mathrm{Fe}$ & 2.55 \\
\hline${ }^{56} \mathrm{Fe}$ & 2.92 & ${ }^{52} \mathrm{Cr}$ & 0.31 & ${ }^{183} \mathrm{~W}$ & 1.61 & ${ }^{58} \mathrm{Fe}, \mathrm{Ni}$ & 44.47 \\
\hline${ }^{58} \mathrm{Fe}, \mathrm{Ni}$ & 45.09 & ${ }^{53} \mathrm{Cr}$ & 0.81 & ${ }^{184} \mathrm{~W}$, Os & 3.39 & ${ }^{60} \mathrm{Ni}$ & 18.23 \\
\hline${ }^{60} \mathrm{Ni}$ & 19.01 & ${ }^{56} \mathrm{Fe}$ & 0.42 & ${ }^{185} \mathrm{Re}$ & 0.26 & ${ }^{6} \mathrm{Ni}$ & 0.87 \\
\hline${ }^{6} \mathrm{Ni}$ & 0.88 & ${ }^{58} \mathrm{Fe}, \mathrm{Ni}$ & 46.08 & ${ }^{186} \mathrm{~W}$, Os & 2.91 & ${ }^{62} \mathrm{Ni}$ & 2.83 \\
\hline${ }^{62} \mathrm{Ni}$ & 2.93 & ${ }^{60} \mathrm{Ni}$ & 19.34 & ${ }^{187} \mathrm{Re}, \mathrm{Os}$ & \begin{tabular}{|l|l}
0.60 \\
\end{tabular} & \begin{tabular}{|c|}
${ }^{64} \mathrm{Ni}, \mathrm{Zn}$ \\
\end{tabular} & 0.87 \\
\hline${ }^{64} \mathrm{Ni}, \mathrm{Zn}$ & 1.00 & ${ }^{61} \mathrm{Ni}$ & 0.96 & ${ }^{206} \mathrm{~Pb}$ & \begin{tabular}{|l|l}
0.18 \\
\end{tabular} & ${ }^{75} \mathrm{As}$ & 0.12 \\
\hline${ }^{66} \mathrm{Zn}$ & 0.13 & ${ }^{62} \mathrm{Ni}$ & 3.02 & ${ }^{207} \mathrm{~Pb}$ & 0.13 & ${ }^{79} \mathrm{Br}$ & 0.19 \\
\hline${ }^{68 Z n}$ & 0.10 & ${ }^{63} \mathrm{Cu}$ & 0.39 & ${ }^{208} \mathrm{~Pb}$ & \begin{tabular}{|l|l}
0.34 \\
\end{tabular} & ${ }^{81} \mathrm{Br}$ & 0.19 \\
\hline${ }^{79} \mathrm{Br}$ & 0.10 & ${ }^{64} \mathrm{Ni}, \mathrm{Zn}$ & 1.31 & & & ${ }^{90} \mathrm{Zr}$ & 0.39 \\
\hline${ }^{7 \mathrm{Li}}$ & 0.60 & ${ }^{65} \mathrm{Cu}$ & 0.16 & & & ${ }^{92} \mathrm{Sr}$, Mo & 0.14 \\
\hline${ }^{81} \mathrm{Br}$ & 0.10 & ${ }^{66} \mathrm{Zn}$ & 0.37 & & & ${ }^{94} \mathrm{Sr}, \mathrm{Mo}$ & 0.16 \\
\hline${ }^{138} \mathrm{Ba}, \mathrm{La}, \mathrm{Ce}$ & 0.20 & ${ }^{68} \mathrm{Zn}$ & 0.20 & & & \begin{tabular}{|l|}
${ }^{107} \mathrm{Ag}$ \\
\end{tabular} & 1.37 \\
\hline${ }^{182} \mathrm{~W}$ & 3.73 & & & & & \begin{tabular}{|l|l|}
${ }^{109} \mathrm{Ag}$ \\
\end{tabular} & 1.39 \\
\hline${ }^{183} \mathrm{~W}$ & 1.92 & & & & & ${ }^{140} \mathrm{Ce}$ & 0.78 \\
\hline${ }^{184} \mathrm{~W}$ & 4.33 & & & & & \begin{tabular}{|l|l|}
${ }^{142} \mathrm{Ce}, \mathrm{Nd}$ \\
\end{tabular} & 0.10 \\
\hline${ }^{186} \mathrm{~W}$, Os & 4.29 & & & & & ${ }^{182} \mathrm{~W}$ & 3.49 \\
\hline${ }^{206} \mathrm{~Pb}$ & 0.26 & & & & & ${ }^{183} \mathrm{~W}$ & 1.90 \\
\hline${ }^{207} \mathrm{~Pb}$ & 0.50 & & & & & ${ }^{184} \mathrm{~W}$, Os & 4.17 \\
\hline \multirow[t]{4}{*}{${ }^{208} \mathrm{~Pb}$} & 0.56 & & & & & \begin{tabular}{|l|l|}
${ }^{185} \mathrm{Re}$ \\
\end{tabular} & 0.38 \\
\hline & & & & & & ${ }^{1806} \mathrm{~W}$, Os & 3.72 \\
\hline & & & & & & \begin{tabular}{|l|}
187 \\
Re, Os
\end{tabular} & 0.60 \\
\hline & & & & & & 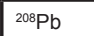 & 0.17 \\
\hline
\end{tabular}

the absence of a calorimeter. A mixture of nickel powder with lithium aluminum hydride weighing $1.5 \mathrm{~g}$ was used as fuel. The fuel contained pieces of tungsten wire with a total mass of $0.77 \mathrm{~g}$. The reactor operated from June 14 to July 24, 2016, producing surplus

Table 7.

The ratio of nickel isotopes in fuel VV3 before and after reactor operation.

\begin{tabular}{|l|c|c|c|c|c|}
\hline \multicolumn{1}{|c|}{$\%$} & ${ }^{58} \mathrm{Ni}$ & ${ }^{60} \mathrm{Ni}$ & ${ }^{61} \mathrm{Ni}$ & ${ }^{62} \mathrm{Ni}$ & ${ }^{64} \mathrm{Ni}$ \\
\hline Initial fuel & 65.93 & 27.98 & 1.19 & 3.98 & 0.91 \\
\hline Surface & 65.79 & 27.61 & 1.37 & 4.31 & 0.91 \\
\hline Deep layer & 66.36 & 27.20 & 1.29 & 4.23 & 0.91 \\
\hline Natural ratio & 68.27 & 26.10 & 1.13 & 3.59 & 0.91 \\
\hline
\end{tabular}

power up to $330 \mathrm{~W}$. A total of $790 \mathrm{MJ}$ of excess heat was generated.

After the experiment was finished, the spent fuel, which looked like a drop-shaped ingot, was extracted from it. It was analyzed at Vernadsky Institute of Geochemistry and Analytical Chemistry RAS using the ICP-MS method, with separate analyzes of the surface and deeper layers. Partially the results of the analysis are shown in Table 6. In addition to the data for the samples recovered from the reactor after its operation, information is given on the content of isotopes in the initial fuel, including tungsten wires embedded in it.

It can be seen that the isotopic composition of fuel as a result experiment has changed noticeably. The content of boron, copper, cerium and silver increased significantly.

Just as in the above-described reactors, the data on the investigated samples, although slightly different from the natural ratio, differ insignificantly between each other (Table 7).

\section{REACTOR KV3}

KV3 reactor (Fig. 13) operated from December 20, 2016 until January 31, 2017, with an excess power of 100-200 watts. The integrated excess energy during the whole operating time of $\mathrm{KV} 3$ reactor is about $400 \mathrm{MJ}$. The main difference from the previous reactors is that it was loaded with 1.8 grams of nickel powder without an admixture of lithium aluminum hydride. Saturation with hydrogen was carried out by keeping it in hydrogen gas. In addition, unlike the above-described reactors, it had not a ceramic but a quartz outer tube. The heater

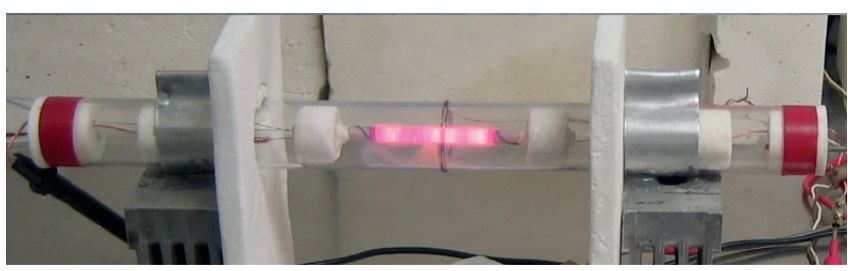

Fig. 13. Reactor KV3 at the beginning of work. 
Table 8.

Isotope content (atomic \%) in fuel and near the active zone of the KV3 reactor before and after reactor operation. Isotopes with a content $>0.1 \%$ are shown.

\begin{tabular}{|l|l|l|l|l|l|}
\hline \multicolumn{5}{|c|}{ Before } \\
\hline \multicolumn{2}{|c|}{ Initial fuel } & \multicolumn{2}{c|}{ Ceramics } & \multicolumn{2}{c|}{ Heater wire } \\
\hline${ }^{23} \mathrm{Na}$ & 0.33 & ${ }^{27} \mathrm{Al}$ & 88.15 & ${ }^{23} \mathrm{Na}$ & 0.47 \\
\hline${ }^{39} \mathrm{~K}$ & 0.38 & ${ }^{23} \mathrm{Na}$ & 1.98 & ${ }^{29} \mathrm{Si}$ & 0.27 \\
\hline${ }^{56} \mathrm{Fe}$ & 0.45 & ${ }^{24} \mathrm{Mg}$ & 0.82 & ${ }^{39} \mathrm{~K}$ & 0.40 \\
\hline${ }^{58} \mathrm{Fe}, \mathrm{Ni}$ & 64.49 & ${ }^{25} \mathrm{Mg}$ & 0.12 & ${ }^{44} \mathrm{Ca}$ & 0.12 \\
\hline${ }^{60} \mathrm{Ni}$ & 27.63 & ${ }^{26} \mathrm{Mg}$ & 0.14 & ${ }^{56} \mathrm{Fe}$ & 0.21 \\
\hline${ }^{61} \mathrm{Ni}$ & 1.18 & ${ }^{29} \mathrm{Si}$ & 0.37 & ${ }^{58} \mathrm{Fe}, \mathrm{Ni}$ & 0.12 \\
\hline${ }^{62} \mathrm{Ni}$ & 3.88 & ${ }^{39} \mathrm{~K}$ & 2.10 & ${ }^{182} \mathrm{~W}$ & 20.24 \\
\hline${ }^{64} \mathrm{Ni}, \mathrm{Zn}$ & 1.21 & ${ }^{44} \mathrm{Ca}$ & 0.21 & ${ }^{183} \mathrm{~W}$ & 11.02 \\
\hline & & ${ }^{47} \mathrm{Ti}$ & 0.88 & ${ }^{184} \mathrm{~W}, \mathrm{Os}$ & 24.39 \\
\hline & & ${ }^{48} \mathrm{Ti}, \mathrm{Ca}$ & 0.18 & ${ }^{185} \mathrm{Re}$ & 6.97 \\
\hline & & ${ }^{54} \mathrm{Cr}$ & 0.14 & ${ }^{186} \mathrm{~W}, \mathrm{Os}$ & 22.23 \\
\hline & & ${ }^{56} \mathrm{Fe}$ & 3.17 & ${ }^{187} \mathrm{Re}, \mathrm{Os}$ & 11.85 \\
\hline & & ${ }^{58} \mathrm{Fe}, \mathrm{Ni}$ & 0.28 & ${ }^{198} \mathrm{Hg}, \mathrm{Pt}$ & 0.12 \\
\hline & & ${ }^{60} \mathrm{Ni}$ & 0.11 & ${ }^{200} \mathrm{Hg}$ & 0.14 \\
\hline & & ${ }^{89} \mathrm{Y}$ & 0.13 & ${ }^{202} \mathrm{Hg}$ & 0.13 \\
\hline & & ${ }^{138} \mathrm{Ba}, \mathrm{Ce}$ & 0.17 & ${ }^{208} \mathrm{~Pb}$ & 0.18 \\
\hline
\end{tabular}

\begin{tabular}{|c|c|c|c|c|c|c|c|}
\hline & & & After & & & Substan & \\
\hline Fuel ce & tral zone & Cer & mics & Cer & nics & & \\
\hline${ }^{23} \mathrm{Na}$ & 0.13 & ${ }^{11} \mathrm{~B}$ & 0.13 & ${ }^{64} \mathrm{Ni}, \mathrm{Zn}$ & 0.22 & ${ }^{23} \mathrm{Na}$ & 5.53 \\
\hline${ }^{31} \mathrm{P}$ & 0.11 & ${ }^{23} \mathrm{Na}$ & 15.61 & ${ }^{66} \mathrm{Zn}$ & 0.11 & ${ }^{24} \mathrm{Mg}$ & 0.50 \\
\hline${ }^{39} \mathrm{~K}$ & 0.14 & ${ }^{24} \mathrm{Mg}$ & 1.06 & ${ }^{76} \mathrm{Ge}, \mathrm{Se}$ & 0.20 & ${ }^{27} \mathrm{Al}$ & 0.32 \\
\hline${ }^{56} \mathrm{Fe}$ & 0.23 & ${ }^{25} \mathrm{Mg}$ & 0.13 & ${ }^{88} \mathrm{Sr}$ & 0.21 & ${ }^{29} \mathrm{Si}$ & 1.42 \\
\hline${ }^{58} \mathrm{Fe}, \mathrm{Ni}$ & 65.39 & ${ }^{26} \mathrm{Mg}$ & 0.24 & ${ }^{89} \mathrm{Y}$ & 0.22 & ${ }^{31} \mathrm{P}$ & 0.16 \\
\hline${ }^{60} \mathrm{Ni}$ & 26.15 & ${ }^{27} \mathrm{Al}$ & 6.05 & ${ }^{90} \mathrm{Zr}$ & 0.42 & ${ }^{39} \mathrm{~K}$ & 6.93 \\
\hline${ }^{61} \mathrm{Ni}$ & 1.18 & ${ }^{29} \mathrm{Si}$ & 4.26 & ${ }^{92} \mathrm{Sr}, \mathrm{Mo}$ & 0.22 & ${ }^{44} \mathrm{Ca}$ & 0.88 \\
\hline${ }^{62} \mathrm{Ni}$ & 3.99 & ${ }^{39} \mathrm{~K}$ & 15.26 & ${ }^{94} \mathrm{Sr}, \mathrm{Mo}$ & 0.17 & ${ }^{45} \mathrm{Sc}$ & 0.82 \\
\hline${ }^{63} \mathrm{Cu}$ & 0.84 & ${ }^{43} \mathrm{Ca}$ & 0.26 & ${ }^{109} \mathrm{Ag}$ & 0.10 & ${ }^{54} \mathrm{Cr}$ & 0.26 \\
\hline${ }^{64} \mathrm{Ni}, \mathrm{Zn}$ & 1.14 & ${ }^{44} \mathrm{Ca}$ & 3.15 & 127 & 0.16 & ${ }^{56} \mathrm{Fe}$ & 7.04 \\
\hline${ }^{65} \mathrm{Cu}$ & 0.42 & ${ }^{45} \mathrm{Sc}$ & 2.04 & ${ }^{138} \mathrm{Ba}, \mathrm{Ce}$ & 0.39 & ${ }^{58} \mathrm{Fe}, \mathrm{Ni}$ & 1.80 \\
\hline & & ${ }^{48} \mathrm{TI}, \mathrm{Ca}$ & 0.23 & ${ }^{182} \mathrm{~W}$ & 4.32 & ${ }^{60} \mathrm{Ni}$ & 0.74 \\
\hline & & ${ }^{51} \mathrm{~V}$ & 0.22 & ${ }^{183 \mathrm{~W}}$ & 2.35 & ${ }^{62} \mathrm{Ni}$ & 0.10 \\
\hline & & ${ }^{54} \mathrm{Cr}$ & 0.96 & ${ }^{184} \mathrm{~W}$ & 5.01 & ${ }^{63} \mathrm{Cu}$ & 0.13 \\
\hline & & ${ }^{55} \mathrm{Mn}$ & 0.10 & ${ }^{185} \mathrm{Re}$ & 5.95 & ${ }^{64} \mathrm{Ni}, \mathrm{Zn}$ & 0.15 \\
\hline & & ${ }^{56} \mathrm{Fe}$ & 21.14 & ${ }^{186} \mathrm{~W}$, Os & 4.77 & ${ }^{182} \mathrm{~W}$ & 18.29 \\
\hline & & ${ }^{57} \mathrm{Fe}$ & 0.15 & ${ }^{203} \mathrm{TI}$ & 0.15 & ${ }^{183} \mathrm{~W}$ & 10.44 \\
\hline & & ${ }^{58} \mathrm{Fe}, \mathrm{Ni}$ & 0.91 & ${ }^{206} \mathrm{~Pb}$ & 0.15 & ${ }^{184} \mathrm{~W}$ & 21.36 \\
\hline & & ${ }^{60} \mathrm{Ni}$ & 0.37 & ${ }^{207} \mathrm{~Pb}$ & 0.15 & ${ }^{186} \mathrm{~W}$, Os & 20.90 \\
\hline & & ${ }^{63} \mathrm{Cu}$ & 0.14 & ${ }^{208} \mathrm{~Pb}$ & 0.40 & ${ }^{198} \mathrm{Hg}$ & 0.17 \\
\hline & & & & & & ${ }^{200} \mathrm{Hg}$ & 0.20 \\
\hline & & & & & & ${ }^{202} \mathrm{Hg}$ & 0.18 \\
\hline & & & & & & ${ }^{208} \mathrm{~Pb}$ & 0.15 \\
\hline
\end{tabular}

was made not from pure tungsten, but from a tungsten-rhenium alloy.

The ICP-MS analysis by Vernadsky Institute of Geochemistry and Analytical Chemistry RAS was used to investigate: fuel and structural materials prior to operation of the reactor, as well as fuel in the central zone and near the edge, powder from the space between the inner and outer tubes, and structural materials after work of the reactor. The results are partially shown in Table 8.

Just as in the reactors Protok 6 and VV3, a lot of tungsten appeared in the space between the inner and outer tubes. In addition to tungsten, a lot of iron, sodium, potassium, nickel, silicon, calcium, scandium and a number of other elements have accumulated there.

Comparing fuel before and after the experiment, one can see a decrease in the content of sodium, potassium and iron. Attention is drawn to the appearance of a significant amount of copper.

A lot of tungsten and rhenium appeared in the inner ceramic tube with fuel, which was wrapped with a heater. Table 9 shows nuclides, the relative content of which in the ceramic tube has increased more than 10-fold.

It can be seen that in addition to tungsten and rhenium, the appearance of which can be

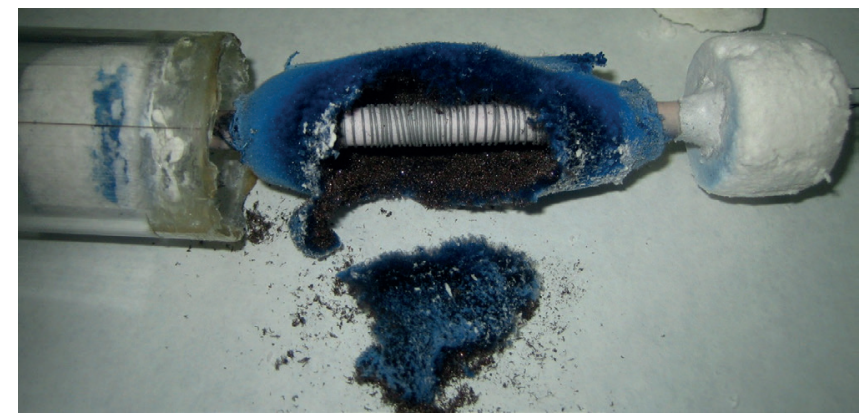

Fig. 14. Reactor KV3 opened after ending of experiment. 
Table 9. Relative content of nuclides (atomic \%) in the ceramic tube before and after the operation of the KV reactor. Nuclides are shown whose content has increased more than 10 times.

\begin{tabular}{|c|c|c|c|c|c|c|c|}
\hline & Before & After & $\begin{array}{l}\text { After/ } \\
\text { before }\end{array}$ & & Before & After & $\begin{array}{l}\text { After/ } \\
\text { before }\end{array}$ \\
\hline${ }^{10} \mathrm{~B}$ & 0.0008 & 0.0318 & 41.8 & ${ }^{114} \mathrm{Cd}, \mathrm{Sn}$ & 0.0005 & 0.0064 & 11.9 \\
\hline${ }^{11} \mathrm{~B}$ & 0.0054 & 0.1277 & 23.4 & ${ }^{116} \mathrm{Cd}, \mathrm{Sn}$ & 0.0022 & 0.0275 & 12.8 \\
\hline${ }^{29} \mathrm{Si}$ & 0.3709 & 4.2603 & 11.5 & ${ }^{117} \mathrm{Sn}$ & 0.0011 & 0.0129 & 12.0 \\
\hline${ }^{43} \mathrm{Ca}$ & 0.0158 & 0.2638 & 16.7 & ${ }^{118} \mathrm{Sn}$ & 0.0024 & 0.0422 & 17.9 \\
\hline${ }^{44} \mathrm{Ca}$ & 0.2123 & 3.1461 & 14.8 & ${ }^{119} \mathrm{Sn}$ & 0.0014 & 0.0165 & 11.7 \\
\hline${ }^{45} \mathrm{Sc}$ & 0.0507 & 2.0384 & 40.2 & ${ }^{120} \mathrm{Sn}, \mathrm{Te}$ & 0.0034 & 0.0670 & 19.5 \\
\hline${ }^{46} \mathrm{Tl}, \mathrm{Ca}$ & 0.0074 & 0.0836 & 11.3 & ${ }^{122} \mathrm{Te}$ & 0.0007 & 0.0101 & 15.0 \\
\hline${ }^{51} \mathrm{~V}$ & 0.0028 & 0.2151 & 78.0 & ${ }^{127}$ & 0.0062 & 0.1589 & 25.7 \\
\hline${ }^{53} \mathrm{Cr}$ & 0.0057 & 0.0753 & 13.3 & ${ }^{128} \mathrm{Te}$ & 0.0002 & 0.0046 & 22.8 \\
\hline${ }^{64} \mathrm{Ni}, \mathrm{Zn}$ & 0.0186 & 0.2224 & 12.0 & ${ }^{124} \mathrm{Te}$ & 0.0008 & 0.0092 & 11.4 \\
\hline${ }^{66 \mathrm{Zn}}$ & 0.0099 & 0.1102 & 11.1 & ${ }^{130} \mathrm{Te}$ & 0.0006 & 0.0101 & 16.7 \\
\hline${ }^{67} \mathrm{Zn}$ & 0.0014 & 0.0211 & 15.0 & ${ }^{182} \mathrm{~W}$ & 0.0076 & 4.3168 & 567.8 \\
\hline${ }^{68} \mathrm{Zn}$ & 0.0080 & 0.0808 & 10.1 & ${ }^{183} \mathrm{~W}$ & 0.0035 & 2.3489 & 671.7 \\
\hline${ }^{72} \mathrm{Ge}$ & 0.0001 & 0.0037 & 27.2 & ${ }^{184} \mathrm{~W}$ & 0.0076 & 5.0087 & 658.8 \\
\hline${ }^{75} \mathrm{As}$ & 0.0001 & 0.0138 & 102.2 & ${ }^{185} \mathrm{Re}$ & 0.0006 & 5.9469 & 9827.0 \\
\hline${ }^{76} \mathrm{Ge}, \mathrm{Se}$ & 0.0115 & 0.1976 & 17.2 & ${ }^{186} \mathrm{~W}$, Os & 0.0089 & 4.7748 & 537.6 \\
\hline${ }^{77 \mathrm{Se}}$ & 0.0001 & 0.0055 & 82.2 & ${ }^{198} \mathrm{Hg}$ & 0.0001 & 0.0321 & 238.5 \\
\hline${ }^{78} \mathrm{Se}, \mathrm{Kr}$ & 0.0028 & 0.0542 & 19.7 & ${ }^{199} \mathrm{Hg}$ & 0.0007 & 0.0248 & 33.5 \\
\hline${ }^{79} \mathrm{Br}$ & 0.0028 & 0.0560 & 20.3 & ${ }^{200} \mathrm{Hg}$ & 0.0004 & 0.0560 & 138.9 \\
\hline${ }^{81} \mathrm{Br}$ & 0.0040 & 0.0790 & 19.6 & ${ }^{202} \mathrm{Hg}$ & 0.0005 & 0.0606 & 128.8 \\
\hline${ }^{83} \mathrm{Kr}$ & 0.0001 & 0.0009 & 13.7 & ${ }^{203} \mathrm{TI}$ & 0.0015 & 0.1498 & 101.2 \\
\hline${ }^{107} \mathrm{Ag}$ & 0.0067 & 0.0863 & 13.0 & ${ }^{204} \mathrm{~Pb}, \mathrm{Hg}$ & 0.0010 & 0.0101 & 10.0 \\
\hline${ }^{109} \mathrm{Ag}$ & 0.0071 & 0.1020 & 14.3 & & & & \\
\hline${ }^{113} \mathrm{Cd}$, In & 0.0001 & 0.0009 & 13.7 & & & & \\
\hline
\end{tabular}

explained by its migration from the heater coil, the boron content in the ceramic tube greatly increased, as well as nuclides with atomic masses of 43-53, 64-83, 107-130, 198-208.

Table 10 shows the results of an analysis of the ratio of nickel isotopes in fuel, as well as in the surrounding ceramic and in the substance accumulated between the inner and outer tubes, before and after the reactor operation. When analyzing the isotope composition, in order to avoid the errors associated with the registration

Table 10.

The ratio of nickel isotopes in fuel and near the core of the KV3 reactor before and after reactor operation.

\begin{tabular}{|l|c|c|c|c|c|}
\hline \multicolumn{1}{|c|}{$\%$} & ${ }^{58} \mathrm{Ni}$ & ${ }^{60} \mathrm{Ni}$ & ${ }^{61} \mathrm{Ni}$ & ${ }^{62} \mathrm{Ni}$ & ${ }^{64} \mathrm{Ni}$ \\
\hline Initiak fuel & 65.93 & 27.98 & 1.19 & 3.98 & 0.91 \\
\hline Fuel after work & 65.74 & 28.17 & 1.20 & 3.98 & 0.91 \\
\hline Substance between tubes & 66.66 & 27.33 & 1.30 & 3.79 & 0.91 \\
\hline Ceramics & 67.65 & 27.37 & 0.82 & 3.26 & 0.91 \\
\hline Natural ratio & 68.27 & 26.10 & 1.13 & 3.59 & 0.91 \\
\hline
\end{tabular}

of ${ }^{64} \mathrm{Zn}$, the ${ }^{64} \mathrm{Ni}$ share was taken from the reference book [30].

It can be seen that the isotopic composition of nickel in fuel before and after the experiment remained practically unchanged. Some differences are noticeable in the results obtained for the ceramic tube and the substance between the tubes. But these results can not be considered accurate, since the concentration of nickel in the samples studied is not high enough for reliable analysis.

In addition to the Vernadsky Institute of Geochemistry and Analytical Chemistry RAS, the analysis of KV3 fuel before and after the experiment, as well as the substance from the space between the inner and outer tubes, was made by the research company Coolescence LLC, Boulder, Colorado, USA. EDS analyzes were performed using an electronic scanning microscope, as well as analyzes using the ICP-MS method. These studies confirmed the insignificant changes in the isotopic composition of the fuel, the appearance in the fuel of about $1 \%$ of copper and the presence of many nuclides in the substance from the space between the tubes10.

\section{DISCUSSION}

Thus, a significant change in the nuclide composition as a result of the operation of the investigated nickel-hydrogen reactors occurs not only in the fuel, but also in the ceramics surrounding the reactor core. In addition, a substance containing sodium, potassium, silicon, iron, boron, calcium, zinc and many other elements accumulates in the cavity between the inner and outer tubes. Especially great amount of tungsten appeared. It is reasonable to assume that the source of tungsten is the hot spiral of the heater. The most understandable mechanism of substance migration is evaporation in places with high temperature and condensation in less heated places. As the measurements show, the temperature of the heater wire reaches $1700^{\circ} \mathrm{C}$. But even at this temperature, the density of tungsten vapor $\left(<10^{-10} \mathrm{~Pa}\right)$ is too low for such mechanism to 
work with a noticeable intensity. Obviously, more complex physicochemical processes take place with the participation of hydrogen and other reagents that may be present in the reactor. It is possible that a number of other elements appear as a result of migration from structural materials, since sodium, potassium, silicon, calcium, iron and a number of other elements are contained in appreciable quantities in the heater wire, thermocouples and in ceramics. However, there are some elements (cobalt, cerium, gallium, germanium, arsenic, selenium, cadmium, tellurium) that appeared in significant quantities, which are practically not presented in the initial fuel and structural materials. This indicates the possibility of their appearance as a result of nuclear transmutations. For example, cerium can be a product of the fission of tungsten

$$
{ }^{182} \mathrm{~W} \rightarrow{ }^{140} \mathrm{Ce}+{ }^{42} \mathrm{Ca}+4 \mathrm{e}+76,04 \mathrm{MeV}
$$

Attention is drawn to the appearance of a significant amount of copper in the fuel of the KV3 reactor $\left(0.84 \%{ }^{63} \mathrm{Cu}\right.$ and $\left.0.42 \%{ }^{65} \mathrm{Cu}\right)$ with a total mass of about $20 \mathrm{mg}$. It can be assumed that this is due to the course of nuclear reactions given below

$$
\begin{aligned}
& { }^{62} \mathrm{Ni}+{ }^{1} \mathrm{H} \rightarrow{ }^{63} \mathrm{Cu}+6.125 \mathrm{MeV} \\
& { }^{64} \mathrm{Ni}+{ }^{1} \mathrm{H} \rightarrow{ }^{65} \mathrm{Cu}+7.450 \mathrm{MeV}
\end{aligned}
$$

About $200 \mathrm{MJ}$ are released as a result of the reactions (4), when $20 \mathrm{mg}$ of copper is formed. This energy release does not contradict the total excess heat release in the KV3 reactor (about $400 \mathrm{MJ}$ ). In addition to heat generation, the appearance of such a quantity of copper should cause a decrease in the relative content of ${ }^{62} \mathrm{Ni}$ by $0.8 \%$ and ${ }^{64} \mathrm{Ni}$ by $0.4 \%$. The data presented in Table 8 does not show such changes. It should be noted that the predicted changes lie within the limits of a possible measurement error, and the ${ }^{64} \mathrm{Ni}$ content is generally difficult to measure reliably due to uncontrolled additions of ${ }^{64} \mathrm{Zn}$.

\section{CONCLUSION}

Numerous experiments conducted in different laboratories, confirm the allocation in Nickel-hydrogen systems, thermal energy, many times exceeding the heat dissipation possible in chemical processes. The level of accumulated empirical knowledge in this area allows us to reflect on the transition from experimental models to a variety of practical applications, extremely efficient and environmentally friendly technologies.

In the course of processes in nickel-hydrogen systems, the changes of the elemental and isotopic composition of matter are detected. This indicates that an anomalously high heat generation in these systems is probably related to transformations at the nuclear level. The fact that such transformations occur at very low nuclear standards, temperatures, and the lack of hard nuclear radiations and radioactivity, indicates the need to look for unusual approaches to explain the detected effects. The problem is that the explanation is not confined to finding ways of overcoming the Coulomb barrier to the close approach and merging of the nuclei [13]. The most mysterious is the absence (or very small intensity) of nuclear radiation in the process of cold transmutations and education only isotopes that do not exhibit radioactivity.

1. The isotopic and elemental composition of the substance in four nickel-hydrogen reactors of various designs with an excess energy output from 100 to $790 \mathrm{MJ}$ has been analyzed. Not only the changes in fuel, but also the materials adjacent to the active zone have been investigated. In addition, the composition of the substance accumulating in the cavity of the reactor near the active zone has been studied.

2. There were no significant changes in the isotopic composition of nickel and lithium, except for the analysis of the fuel of the AP2 reactor at Uppsala University (Sweden).

3. A significant increase in the concentration of impurities of a number of nuclides has been detected not only in fuel, but also in structural 
elements adjacent to the active zones of the reactors. In addition to tungsten and rhenium, the appearance of which can be explained by migration from the heater coil, the content of boron increased greatly, as well as nuclides with atomic masses of 43-53, 64-83, 107-130, 198-208.

4. In the substance that was found in the cavity of the reactor near the active zone, in addition to tungsten, a lot of iron, sodium, potassium, nickel, silicon, calcium, scandium and a number of other elements accumulated.

\section{REFERENCES}

1. Fleishmann $\mathrm{M}$, Pons $\mathrm{S}$, Hawkins $\mathrm{M}$. Electrochemically induced nuclear fusion of deuterium. J. Electroanal. Chem., 1989, 261:301-308.

2. Filimonenko IS. Demonstratsionnaya termoemissionnaya ustanovka dlya yadernogo sinteza [Demonstrational therm-emission device for nuclear fusion]. Materials 3 Sci. Symp. "Perestroyka estestvoznaniya [Restructuring of Natural history"-92, Volgodonsk, Russia, 17-19 apr. 1992 (in Russ.).

3. Velikodny VYu, Eremeev AV, Kazennov AYu, etc. Experiments on the registration of abnormally high relative heat output during high-voltage electrolysis of heavy water. Materials 12 Ross. Conf. on cold transmutation of nuclei of chemical elements, Sochi, 19-26 Sept. 2004, p.98-109 (in Russ.).

4. Pan'kov VA, Kuzmin BP. Demonstrational technique of synthesis of elements from water in the plasma of electric discharge. Actual problems of modern science, 2008, 5(44):112-116 (in Russ.).

5. Vaimoprevrashcheniya kbimicheskikh elementov [nterconversion of chemical elements]. Under the editorship of V.F. Balakirev. Ekaterinburg, Ural Branch of RAS Publ., 2003, 64 p.

6. Controlled Nucleosynthesis. Breakthroughs in Experiment and Theory. Series: Fundamental Theories of Physics. Vol. 156. Eds. Adamenko S, Selleri F, Merwe A., 780 p., Springer, 2007.

7. Urutskoev LI, Liksonov VI. Observation of transformation of chemical elements during electric discharge. - http://arxiv.org/ftp/ physics/papers/0101/0101089.pdf.

8. Bazhutov YuN, Velikodny VYu, Grishin VG et al. Neutrons, Gamma-Rays \& Tritium Diagnostic at Electrolysis in Water Solutions. Proc. 13 Intern. Conf. on Condensed Matter Nuclear Science (ICCF13). Sochi, June 25-July 1, 2007, p. 156-169.

9. Parkhomov AG. Cold transmutation of nuclei: strange results and attempts at their explanations. Zhurnal formiruyushchikhsya napravleniy nauki (ZhFNN) [Journal of unconventional science], 2013, 1(1):71-76 (in Russ.).

10. Kervran C. Transmutations Biologique et Physique Moderne. Paris, Librairie Maloine S.A., 1982.

11. Vysotskii VI, Kornilova AA. Nuclear fusion and transmutation of isotopes in biological systems. Wiley, New York, 2003, p. 161.

12. Focardi S, Habel R, Piantelli F. Anomalous Heat Production in Ni-H Systems. Nuovo Cimento, 1994, 107A(1):163-167.

13. Focardi S, Gabbani V, Piantelli F et al. Large excess heat production in Ni-H systems. Nuovo Cimento, 1998, 111A(11):1233-1242.

14. Battaglia A, Daddi L, Focardi S et al. Neutron emission in Ni-H systems. Nuovo Cimento, 1999, 112A(9):921-931.

15. Focardi S, Gabbanib V, Piantelli F et al. Evidence of electromagnetic radiation from $\mathrm{Ni}-\mathrm{H}$ Systems. Proc. 11 Intern. Conf. on Condensed Matter Nuclear Science (ICCF-11), 2004, Marseille, France. http://www.nichenergy.com.

16. http://www.nichenergy.com.

17. Bazhutov YyN, Koretsky VP, Parkhomov AG. Research of radiation effects at saturation $\mathrm{LaNi}_{5}$, nickel and beryllium with hydrogen. Materials 19 Ross. Conf. on cold transmutation of nuclei and ball lightning. Krinitsa, Krasnodarsky Krai, 3-10 September 2012, pp. 129-142 (in Russ.).

18. Celani F, Marano EF, Spallone A. Cu-Ni-Mn alloy wires, with improved sub-micrometric surfaces, used as LENR device by new transparent, dissipation-type, calorimeter. J. Condens. Matter Nucl. Sci., 2014, 13:56-67.

19. Takahashi A, Kitamura A, Taniike A et al. Anomalous exothermic and endothermic data observed by nano-Ni-composite samples. - https://mospace.umsystem.edu/xmlui/ handle/10355/36494.

20. Bazhutov YuN. The heat generator Rossi and Focardi. Izobretatelstvo, 2012, 12(1):49-59 (in Russ.).

21. Patent 0001387256, Italy. International application WO/2009/125444. Date: Aug.04, 2008. 
22. Levi G, Foschi E, Höistad B. et al. Indication of anomalous heat energy production in a reactor device. - arXiv:1305.3913v3 [physics.gen-ph].

23. Levi G, Foschi E, Höistad B. Observation of abundant heat production from a reactor device and of isotopic changes in the fuel. - http:// www.sifferkoll.se/sifferkoll/wp-content/ uploads/2014/10/LuganoReportSubmit.pdf.

24. Parkhomov AG. Otchet mezhdunarodnoy komissii ob ispytanii vysokotemperaturnogo teplogeneratora Rossi [Report of theinternational Commission on the testing of high-temperature heat generator Rossi]. ZhFNN, 2014, 2(6):57-61 (in Russ.). - http://www.unconv-science.org/ pdf/6/parkhomov2-ru.pdf.

25. Parkhomov AG. Issledovanie analoga vysokotemperaturnogo teplogeneratora Rossi [The study analogue high-temperature heat generator Rossi]. ZhFNN, 2015, 3(7):68-72 (in Russ.) - http://www.unconv-science.org/ pdf/7/parkhomov-ru.pdf.

26. Parkhomov AG. Nikel-vodorodnye reaktory, sozdannye posle publikatsii otcheta ob eksperimente $\mathrm{V}$ Lugano [Nickel-hydrogen reactors, created after the publication of the report on the experiment in Lugano]. $Z h F N N$, 2016, 11(11):58-62 (in Russ.) - http://www. unconv-science.org/n11/parkhomov.

27. Alabin KA, Andreev SN, Parkhomov AG. Rezultaty analiza izotopnogo i elementnogo sostava topliva nikel-vodorodnykh reatorov [The results of the analysis of the isotopic and elemental composition of the fuel Nickel-hydrogen reactors]. ZhFNN, 2015, 3(10):49-53 (in Russ.) - http:/ /www.unconvscience.org/pdf/10/alabin-ru.pdf.

28. Parkhomov AG. Rezultaty ispytaniy novogo varianta analoga vysokotemperaturnogo teplogeneratora Rossi [The results of the tests of the new version of analogue high-temperature heat generator Rossi]. ZhFNN, 2015, 3(8):34-38 (in Russ.) - http://www.unconv-science.org/ pdf/8/parkhomov-ru.pdf.

29. Parkhomov AG. Dlitelnye ispytaniya nikelvodorodnykh teplogeneratorov $\mathrm{v}$ protochnom kalorimetre [Long-term testing of Nickel-hydrogen generators in a flow calorimeter]. ZhFNN, 2016, 4(12-13):74-79 (in Russ.) - http://www.unconvscience.org/pdf/12/parkhomov-ru.pdf.
30. Fizicheskie velichiny. Spravochnik [A physical values. Handbook]. Edited by I. S. Grigoriev and E. Z. Meilikhova Moscow, Energoatomizdat Publ., 1991, 1232 p. 